
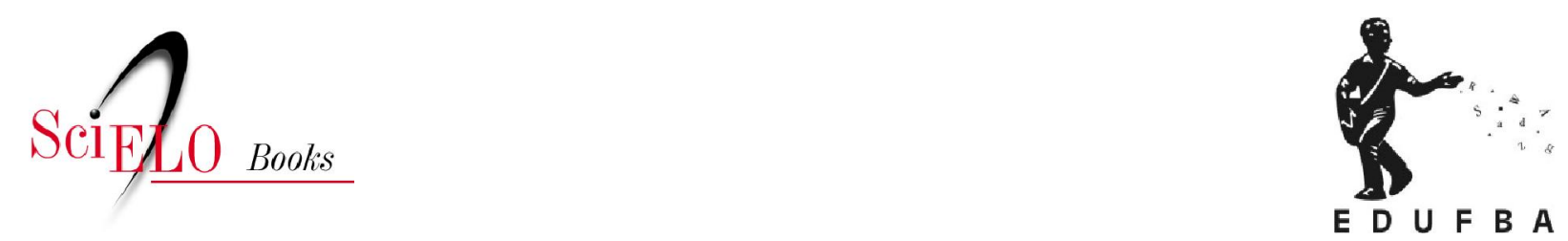

\title{
Algumas abordagens da educação sexual na deficiência intelectual
}

\author{
Lília Maria de Azevedo Moreira
}

\section{SciELO Books / SciELO Livros / SciELO Libros}

MOREIRA, LMA. Algumas abordagens da educação sexual na deficiência intelectual [online]. 3rd ed. Salvador: EDUFBA, 2011, 147p. Bahia de todos collection. ISBN 978-85-232-1157-8. Available from SciELO Books <http://books.scielo.org $>$.

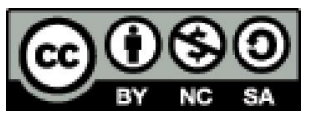

All the contents of this work, except where otherwise noted, is licensed under a Creative Commons Attribution-Non Commercial-ShareAlike 3.0 Unported.

Todo o conteúdo deste trabalho, exceto quando houver ressalva, é publicado sob a licença Creative Commons Atribuição Uso Não Comercial - Partilha nos Mesmos Termos 3.0 Não adaptada.

Todo el contenido de esta obra, excepto donde se indique lo contrario, está bajo licencia de la licencia Creative Commons Reconocimento-NoComercial-CompartirIgual 3.0 Unported. 


\section{Algumas Abordagens da Educação Sexual na Deficiência Intelectual}

Lília Maria de Azevedo Moreira 


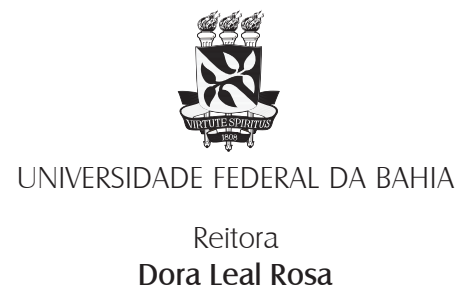

Vice - Reitor

Luiz Rogério Bastos Leal

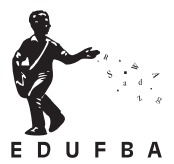

EDITORA DA UNIVERSIDADE FEDERAL DA BAHIA

Diretora

Flávia Goullart Mota Garcia Rosa

\author{
Conselho editorial \\ Alberto Brum Novaes \\ Ângelo Szaniecki Perret Serpa \\ Caiuby Alves da Costa \\ Charbel Ninõ El-Hani \\ Cleise Furtado Mendes \\ Dante Eustachio Lucchesi Ramacciotti \\ Evelina de Carvalho Sá Hoisel \\ José Teixeira Cavalcante Filho \\ Maria Vidal de Negreiros Camargo
}




\section{Algumas Abordagens da Educação Sexual na Deficiência Intelectual}

$3^{a}$ edição 


\section{Capa e projeto gráfico}

Letícia Miranda

Ilustraçōes da Capa

Jane Lydia de Azevedo Moreira

Editoração

Letícia Miranda

Revisão

Flávia Goullart Mota Garcia Rosa

Moreira, Lília Maria de Azevedo.

Algumas abordagens da educação sexual na deficiência intelectual / Lília Maria de Azevedo Moreira. - 3. ed. - Salvador : EDUFBA, 2011.

147 p. : il.

ISBN: 978-85-232-0809-7

1. Educação sexual para pessoas com deficiência intelectual. 2. Deficiencia intelectual - Comportamento sexual. I. Título.

CDD 371.92 - 22. ed.

EDUFBA

Rua Barão de Geremoabo, s/n

Campus de Ondina, Salvador-BA

CEP 40170-290

Tel/fax: (71) 3263- 6164

www.edufba.ufba.br

edufba@ufba.br 


\section{Colaboração}

Adelina Rebouças

Ana Paula Pereira Gomes

Antônio de Souza Batista

Clarissa Lima Falcão

Eliane C. Passos

Jorgilene S. R. Lima

Mariana de Oliveira Rodrigues

Paola Barreto de Oliveira

Renata Brito Araújo

Rodrigo Freire de Oliveira

Tereza Cristina C. Araújo

Yara G. M. de Matos

\section{Ilustraçōes}

Jane Lydia de Azevedo Moreira 



\section{Alos portadores de}

necessidades especiais.

particularmente à pessoa com deficiência intelectual.

Esperando contribuir para o desenvolvimento das suas potencialidades e para o usufruto de sua cidadania. 



\section{Sumário}

Apresentação por Lília Maria A. Moreira 11

Prefácio por Fabiana Mascarenhas 13

Préfácio por Cláudia Werneck 17

A educação sexual como ação inclusiva 23

A educação sexual para pessoas com distúrbios genéticos 29

Deficiência intelectual: conceitos e causas 35

O papel dos pais e dos educadores na educação sexual da pessoa com deficiência intelectual 43

Questionamento sobre a sexualidade da pessoa com deficiência intelectual 49

Dinâmicas de grupo e oficinas 57

Aplicação do programa em diferentes instituições especializadas no estado da Bahia 89

Desenvolvimento e crescimento humano: da concepção à puberdade 113

Métodos contraceptivos e suas características 125

Doenças sexualmente transmissíveis 139

Referências 143 



\section{Apresentação}

O desenvolvimento sexual é uma etapa fundamental na vida do ser humano e diante do fato que a maioria das pessoas com deficiência intelectual chegam à puberdade com as mudanças decorrentes da maturação sexual, é essencial que tabus referentes a este tema sejam revistos.

Na vivência do aconselhamento genético que realizamos, em serviço oferecido à comunidade geral desde 1986, ouvimos, muitas vezes, de familiares e profissionais, declaraçōes a respeito da sua preocupação com a sexualidade da pessoa com deficiência intelectual, assunto de manejo difícil nas diversas circunstâncias. Os filhos muitas vezes não entendem as limitações e dificuldades que lhe são impostas e os pais sentem-se preocupados com a socialização e com questões como o abuso sexual, adotando frequentemente atitudes de supreproteção ao invés do equilíbrio entre a necessária liberdade e a vigilância. Profissionais, docentes e técnicos mostram interesse no assunto mas apontam entre as dificuldades, a falta de material instrucional adequado.

Acreditando na abrangência do aconselhamento genético como prática interdisciplinar, também visando, melhoria na prevenção, qualidade de vida e adaptação social da pessoa com deficiência mental, elaboramos este livro. Para o seu preparo, reunimos a pouca literatura pertinente, relatos de experiências pedagógicas diversas, a nossa experiência, e elaboramos uma seqüência de oficinas e dinâmicas de grupo, privilegiando atitudes que possam levar ao desenvolvimento do pensamento abstrato, tra- 
balho com o corpo, conhecimento dos limites, manejo de preconceitos, acrescidos de textos de apoio, solicitados por pais e profissionais que participaram dos nossos cursos de extensão.

A publicação da presente edição é o resultado da grande receptividade a esse trabalho por parte das pessoas com deficiência intelectual, suas famílias e profissionais da área. As primeiras ediçōes, publicadas em 1995 e em 1998, foram utilizadas em diversas atividades de extensão da UFBA e divulgadas em instituiçōes especializadas e centros de extensão de outras universidades. Foram também realizados treinamentos técnicos e palestras que proporcionaram a preparação de profissionais e o desenvolvimento afetivo de numerosas pessoas com deficiência intelectual. A demanda por novas discussões, diante do movimento inclusivo, mostrando que a temática continua atual, nos levou a preparar uma nova edição.

Esperamos que esta edição, revista e ampliada, seja tão bem recebida quanto as anteriores e venha a contribuir para a inclusão e qualidade de vida da pessoa com deficiência intelectual e da sua família.

Lilia Maria A. Moreira 


\section{Prefácio}

Ao ser pautada para fazer uma matéria no Jornal A Tarde em 2005, abordando as dificuldades enfrentadas pelas pessoas com necessidades especiais no processo de inclusão educacional, tive a oportunidade de conhecer o trabalho da Dra . Lília Maria de Azevedo Moreira e ouvi da pesquisadora a seguinte declaração:

Apesar dos avanços significativos que estamos tendo no movimento inclusivo, não podemos esquecer que, assim como nas pessoas sem deficiência, a implementação de programas educacionais que visam o desenvolvimento integral das pessoas com de necessidades especiais não pode excluir a educação sexual.

Esta análise da professora mudou o rumo de minha reportagem. Inicialmente, a proposta era fazer apenas uma matéria para o caderno de cidade, mas a partir de então decidimos ampliar o debate e levar o assunto à seção de ciência e saúde, chamado Observatório, publicada semanalmente pelo referido jornal. A grande repercussão na época provou que acertamos na escoIha.

E pudemos verificar isso porque tais palavras não estavam empregadas apenas no discurso de alguém que pesquisa e trabalha com o assunto desde 1986, mas se refletem também no relato de familiares e educadores que convivem com os pessoas com necessidades especiais. 
Nas entrevistas realizadas para a produção da matéria, publicada na edição do dia 6 de outubro de 2005, pude perceber que muitos acreditam na falsa idéia imposta pela sociedade de que o sexo e a sexualidade são atributos restritos a indivíduos adultos e ditos "saudáveis".

Se falar sobre sexo traz, muitas vezes, constrangimento e discriminação, quando o tema passa a ser a sexualidade em um portador de necessidade especial, esses sentimentos são intensificados, na maioria dos casos, através da repressão, silêncio e do próprio preconceito.

Deste modo, ignorar a sexualidade da pessoa com deficiência intelectual, para alguns, ainda é mais fácil do que reconhecêlos como pessoas sexuadas e que, assim como tantos outros, têm desejos que não podem e não devem ser reprimidos.

É esse importante e necessário assunto que a professora Lília e sua equipe tratam no livro " Algumas abordagens sobre a educação sexual na deficiência intelectual ". A publicação, que já está em sua $3^{a}$ edição, é resultado de estudos realizados com pais, deficientes intelectuais e profissionais nos quais buscou-se identificar aspectos da sexualidade em adolescentes com deficiência intelectual.

Nele, a autora, com a autoridade de professora titular de Genética Humana do Instituto de Biologia na Universidade Federal da Bahia (UFBA), traz o leitor para uma realidade que, seja por desconhecimento ou por preconceito, muitos não querem ver: o desenvolvimento intelectual e anatômico nem sempre é comprometido na pessoa com deficiência intelectual, que é sexuada, atua e percebe a sua sexualidade que deve ser respeitada.

Por meio de uma linguagem clara e bastante didática, a professora fala sobre a educação sexual como ação inclusiva, do papel dos pais e educadores nesse processo e das possíveis conseqüências da repressão sexual nestes indivíduos, entre elas, a 
redução das possibilidades dele se tornar um ser psiquicamente integral.

Além disso, traz ainda um programa educacional que utiliza atividades de relaxamento, dinâmicas de grupo e oficinas de educação com as orientaçōes e cuidados que se deve ter para que o deficiente mental tenha uma vida sexual saudável.

A relevância do trabalho da pesquisadora e da publicação desta $3^{a}$ edição se torna ainda mais evidente quando sabemos que a deficiência intelectual é um distúrbio de desenvolvimento freqüente, atingindo mais de dois milhōes de brasileiros.

Este livro é uma contribuição fundamental na luta pela conscientização dos direitos das pessoas com deficiência intelectual. E é, com certeza, não só um guia para pais e educadores, mas um trabalho para ser lido com prazer por todos aqueles que se interessam e respeitam a vida humana.

Salvador, 18 de Fevereiro de 2007

Fabiana Mascarenhas

Jornalista 



\section{Prefácio}

Em 1995, assisti a Dra Lília Maria de Azevedo Moreira proferir uma palestra para pais e profissionais num seminário promovido pela Clínica Samarão Brandão, aí em Salvador. O tema era "Aspectos clínicos e genéticos da Síndrome de Down". Encantei-me com sua fala. Um discurso atualizado interdisciplinarmente, atento e moderno. Jamais esqueceria essa primeira impressão. Desde 1991, como jornalista, pesquiso sobre deficiência e pouquíssimas vezes encontrei médicos e cientistas com a sua sensibilidade.

A Dra Lília é o que eu considero uma "especialista certo". O "especialista certo" entende de ciência, de tecnologia e também do Homem. E deste último tipo de conhecimento costuma não abrir mão. Este especialista, que se tornará o herói do século XXI, nem sempre está em cargos públicos importantes como a reitoria de uma universidade ou a direção de um hospital. Mas pode ser encontrado acompanhando de perto os problemas que ele estuda ou cuida. E sabe que é dessa parceria que nascerá o verdadeiro saber.

Assim, desde esse encontro em Salvador, eu e a Dra Lília de alguma forma mantivemos contato. Trocamos correspondências, encontramo-nos em outros eventos, recebi a sua primeira obra "Manual sobre educação sexual de deficientes mentais" e o li com grande interesse. Indique-o para muitas pessoas. Agora sou convidada a escrever o prefácio dessa segunda publicação, que leva o nome "Algumas Abordagens na Educação Sexual de Deficientes Mentais". Aceito honrada. Desejo registrar minha opinião pessoas 
com deficiência mental têm o direito de amadurecer e de serem orientadas em todos os sentidos, incluindo a área afetivo-sexual.

O cinema acaba de abordar o assunto. No filme "O Oitavo Dia", de Jacó Van Dormael, o ator belga, com Síndrome de Down, Pascal Duquenne, que no filme interpreta George, também um rapaz com Síndrome de Down, tem uma cena romântica com Nathalie, como ele portadora dessa síndrome genética. Os dois conseguem ficar sozinhos, deitam-se, ele começa a tirar a roupa e ela diz, resumidamente, algo assim: "Não podemos fazer amor, meu pai não deixa". George responde: "Mas ele faz". Nathalie esboça um sorriso e diz: "Mas ele ganha dinheiro, é independente, é até diretor de uma empresa". George complementa: "Mas com ele eu não quero fazer amor". Os dois riem muito e as cenas a seguir nos induzem a pensar que se amaram. Vale lembrar que por sua atuação neste filme Pascal Duquenne dividiu o prêmio de melhor ator do Festival de Cannes de 1996 com Daniel Auteil, justamente o ator com quem contracena. Daniel Auteil interpreta um executivo que muda o seu jeito de ser depois que interage com George por alguns dias. Os dois viram amigos e se ajudam mutuamente. Provam que a relação de amizade de pessoas deficientes e não deficientes é uma relação de troca como outra qualquer. Todos ganham e todos perdem.

Esta interação entre pessoas "diferentes" na escola, no trabalho, no lazer, no turismo, na sociedade etc, faz refletir sobre o papel de cada um de nós, pessoas, direta ou indiretamente, ligadas à área da deficiência, na construção de um mundo para todos. É o que a ONU chama de sociedade inclusiva, uma sociedade reestruturada de tal forma que possa contemplar todas as necessidades de cada cidadão, incluindo os excluídos históricos, como as pessoas com deficiência intelectual. A ONU está otimista e propõe que nos unamos para que até o ano de 2010 possamos estar vivendo numa sociedade inclusiva global. Inclusão também 
é garantir às pessoas o direito de terem as informaçōes de que necessitam para uma melhor qualidade de vida.

A caminho da sociedade inclusiva, profissionais de todas as áreas deverão ficar mais atentos. Que papel desempenham na construção de um mundo para todos? Como é possível ir além do que tradicionalmente se espera de um jornalista, de um professor e de um médico? Incluir é humanizar caminhos. O trabaIho de cada profissional é um caminho. Só humanizando caminhos será possível modificar mentalidades e atitudes. Será possível fortalecer a sociedade civil brasileira.

Parece-me, é o que a Dra Lília e sua equipe vêm se dispondo a fazer. Abraços, parabéns e ainda mais sucesso!

Rio de Janeiro, 30 de agosto de 1997.

(2a Edição)

Cláudia Werneck Jornalista, responsável pelo projeto

"Muito prazer, eu existo" 



\section{"Reconhecer a desigualdade}

biológica e buscar erradicar a desigualdade social é um dos pressupostos para a garantia da sobrevivência do homem como espécie."

Gilberto de Lima Garcias. 2002. 



\section{1 \\ A educação sexual como ação inclusiva}

O início deste século foi marcado por avanço significativo no movimento inclusivo que, partindo da premissa da pluralidade da natureza humana, busca formas de valorização e reconhecimento de todas as pessoas, com suas diferenças genéticas, culturais e sociais.

A escola constitui o principal ambiente de aprendizado e desenvolvimento e o esgotamento do modelo tradicional de educação levou a implantação de um novo modelo inclusivo, que valoriza as diferenças e a participação de todos no processo educativo.

A inclusão escolar difundida a partir de 1985, apresenta como premissa básica a implantação de um sistema educacional que valoriza a diversidade, seguindo as diretrizes da Declaração de Salamanca que defende:

- a aceitação das diferenças individuais,

- a valorização da diversidade humana,

- o direito de pertinência,

- a aprendizagem cooperativa,

- o reconhecimento das minorias sociais,

- a busca da qualidade de vida através do direito à cidadania. 
Maria Tereza Eggler Mantoan (2006) defende a inclusão como um "sonho possível" e ressalta que

\begin{abstract}
A possibilidade de ensinar todos os alunos, sem discriminação e sem práticas do ensino especializado, deriva-se de uma reestruturação do projeto pedagógico-escolar como um todo e das reformulaçōes que este projeto exige da escola, para que ela se ajuste a novos parâmetros de ação educativa.
\end{abstract}

A inclusão requer inovações curriculares que nem sempre são bem aceitas e implementadas no modelo pedagógico ainda vigente de seriaçōes e divisão do ensino em disciplinas.

Ensinar a turma toda, sem exceçōes e sem exclusōes como preconiza a referida educadora, significa atender às diferenças dos alunos e adotar uma pedagogia com interpretação dos saberes, decorrente da transversalidade curricular com práticas que levam a construção de conceitos, valores e atitudes.

A implementação de programas educacionais que visem o desenvolvimento integral de pessoas com ou sem deficiência, não pode excluir a educação sexual. Os Parâmetros Curriculares Nacionais (PCN) (MEC, 1997) inserem a Orientação Sexual dentre os temas transversais a serem tratados no Ensino Fundamental. Os temas transversais propostos pelo MEC apresentam um compromisso com a construção da cidadania, liberdade e autonomia, a prática de princípios éticos - respeito, solidariedade e responsabilidade, uso construtivo da cidadania, liberdade e autonomia - e princípios políticos - direitos e deveres do cidadão.

As manifestações da sexualidade ocorrem em todas as faixas etárias e os valores transmitidos pela família, pelos amigos ou veiculados pelos meios de comunicação, são trazidos pelo aluno

\title{
24
}


para dentro da escola que não pode omitir-se de trabalhar com esta temática.

Os Parâmetros Curriculares Nacionais propōem que a escola deva informar e discutir os diferentes tabus, preconceitos, crenças e atitudes existentes na sociedade, preenchendo lacunas nas informaçōes que a criança já possui, ao propiciar informaçōes atualizadas do ponto de vista científico, o que possibilita ao aluno desenvolver atitudes coerentes com os seus valores (MEC, 2000).

Mantoan (2006) observa que nem todas as diferenças levam a inferiorização e do mesmo modo que há diferenças, há também muitas semelhanças entre as pessoas. Tendo em vista este fato, a autora refere Santos (1995) quando afirma que "é preciso que tenhamos o direito de ser diferentes quando a igualdade nos descaracteriza e o direito de sermos iguais quando as diferenças nos inferioriza".

O PCN reconhece o problema complexo da falta de respeito e solidariedade para pessoas com deficiência física e intelecual ao afirmar que "a ignorância muitas vezes completa acerca do que seja, das causas, assim como do encaminhamento que se deve dar em termos educacionais a tais casos, leva a práticas discriminatórias, amparadas em discursos equivocados, que falam apenas de boas intençōes, embora seja comum que atinjam o seu oposto".

Mudanças que levem a aceitação do modelo de inclusão requerem modificaçōes da sociedade como um todo em relação à compreensão do signnificado das deficiências - causas, prevenção, direitos e possibilidades. O conhecimento desses aspectos é fundamental para uma aceitação consciente da natureza plural da sociedade. 

Quero me casar na noite na rua no mar ou no céu quero me casar

Procuro uma noiva

loura morena preta ou azul uma noiva verde uma noiva no ar como um passarinho depressa. que o amor nã̃o pode esperar"

Carlos Drummond de Andrade. 1995 



\section{2}

\section{A educação sexual para pessoas com distúrbios genéticos}

Albert Jacquard (1988) ensina que não há genes bons nem ruins, mas que um bom patrimônio genético deve ser diverso. A diversidade aumenta as chances de adaptação das espécies frente às mudanças ambientais. O fluxo genético mantém esta diversidade, que constitui a riqueza coletiva e a interação com o meio ambiente vai favorecer o valor adaptativo dos genes. Assim, embora a anemia falciforme seja uma condição desfavorável, os portadores do traço, sem a anemia, carregando apenas uma cópia do alelo, apresentam maior resistência à malária na África, onde esta doença é endêmica.

As mutaçōes e as recombinaçōes que surgem no processo de reprodução garantem a manutenção da variação genética nas populaçōes. Genótipos não-adaptativos provocam os chamados distúrbios genéticos que a depender da forma de transmissão e a natureza do fator genético responsável são classificados em cromossômicos, gênicos e multifatoriais.

O aumento da esperança de vida das pessoas que apresentam distúrbios genéticos Ihes tem proporcionado a oportunidade de desenvolvimento sexual-afetivo, com satisfaçōes e também problemas decorrentes deste processo. A falta de autonomia e 
de autoconfiança constitui muitas vezes uma barreira no estabelecimento de relações interpessoais, referentes à amizade e namoros. Modificações no corpo e no comportamento, decorrentes da puberdade, assim como o desenvolvimento psico-afetivo e social, merecem nesses casos, cuidadosa reflexão e orientação.

Dificuldades do desenvolvimento sexual podem ser observadas nas seguintes situaçōes:

- Distúrbios genéticos que acarretam déficit no aprendizado.

- Deficiências físicas sem distúrbio de aprendizado

- Alterações na anatomia e funcionamento dos órgãos sexuais, sem déficits cognitivos.

O primeiro caso é exemplificado pela Síndrome de Down, causada pela presença de cópia extra do cromossomo 21 (trissomia), em suas células. Em 95\% dos casos trata-se de trissomia livre, distúrbio genético de natureza esporádica, com poucas chances de repetição (Figura1).

As demais causas da S. Down, referem-se à presença de células normais e outras com um cromossomo 21 extra, na mesma pessoa (mosaicismo) ou ainda translocação do 21 para outro cromossomo, geralmente o 14, permanecendo o número cromossômico normal mas, funcionalmente havendo excesso de material genético do cromossomo 21. Esta última situação apresenta possibilidades de transmissão hereditária na família.

Os avanços no atendimento à sua saúde e o início precoce de programas psico-pedagógicos, tem proporcionado uma maior expectativa de vida para as crianças Down. Estudos mostram que pessoas com a síndrome apresentam uma sobrevivência de 85\% no primeiro ano de vida e que metade dos afetados estão vivos aos 50 anos (MIKKELSEN e colaboradores, 1990; BAIRD; SADOVNICK, 1989)

\section{0}


O desenvolvimento orgânico/sexual na Síndrome de Down frequentemente ocorre com mudanças lentas mas harmoniosas. Muitas adolescentes apresentam menarca na idade habitual e períodos menstruais com fluxo normal. Investigação feita pela Federação Brasileira das Associaçōes de Síndrome de Down (SHIAVO, 1999) com 383 pessoas com a síndrome revela que a maioria desejava namorar e casar-se, mas o desejo de ter filhos era raramente mencionado.

A aceitação social dessas pessoas tem levado ao surgimento de novos movimentos, como o Dia Internacional da Síndrome de Down, em 21 de março, data escolhida pela Associação Down Syndrome International, considerando os três cromossomos do par de número 21 (dia 21 do terceiro mês do ano).

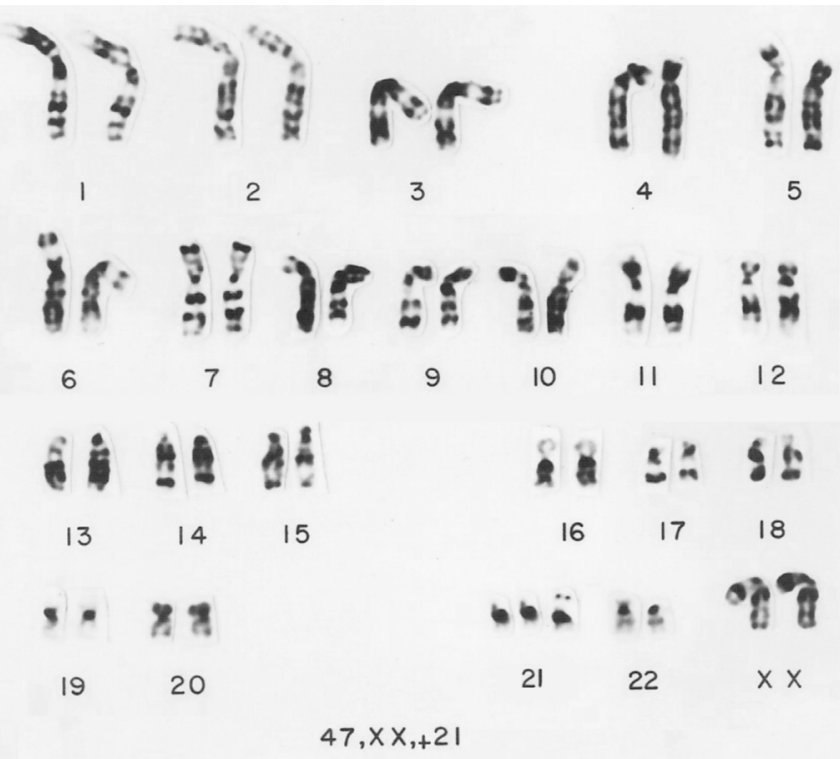

Figura 1-Cariograma de uma pessoa do sexo feminino, com a trissomia livre do cromossomo 21 
Ao lado das importantes conquistas sociais e no mercado de trabalho, algumas pessoas com a Síndrome de Down têm também alcançado um desenvolvimento afetivo adequado, chegando a estabelecer casamentos estáveis.

A segunda situação é exemplificada pela Espinha Bífida, defeito de fechamento do tubo neural de herança multifatorial, que pode acarretar problemas ortopédicos e urológicos. Pessoas com este distúrbio podem ser estigmatizadas no relacionamento com os considerados saudáveis, o que se expressa muitas vezes por isolamento. Soares e colaboradores (2006) citam o caso de uma jovem com Espinha Bífida que diz: "Eu amo minha mãe, mas ela está comigo 24/7 (24 horas ao dia, 7 dias na semana) e com ela é difícil me divertir e relaxar", apresentando-se destituída da sua condição de jovem mulher pela superproteção. Mesmo diante da obrigatoriedade do sistema inclusivo nas escolas, os autores registram preconceitos, intolerância e exclusão.

Distúrbios genéticos que atingem o desenvolvimento genital, podem ser exemplificados pela hiperplasia adrenal congênita, forma de pseudo-hermafroditismo feminino de herança autossômica recessiva, em que devido ao desequilíbrio hormonal a genitália externa não está de acordo com o sexo genético e o gonadal, requisitando intervençōes cirúrgicas para a sua adequação.Na situação referida, o processo educativo permite esclarecer aspectos da anatomia e fisiologia, necessários à compreensão do funcionamento do próprio corpo e do distúrbio apresentado, reforçando através do conhecimento a auto-estima e a autonomia.

A Educação Sexual deve ser levada em conta, na elaboração de programas de incentivo à inclusão social e qualidade de vida para pessoas com distúrbios dessa natureza. 


\section{“Não há ninguém mais solitário do que o pai ou a mãe de uma criança recém-diaginosticada com distürlbio genético"}





\section{$\mathbf{3}$ \\ Deficiência intelectual: conceitos e causas}

As deficiências representam construçōes sociais, muitas vezes associadas a problemas orgânicos. Glat (1995) observa que

A deficiência é uma categoria socialmente construída que se torna incapacitante e restritiva não apenas pelas inerentes limitações orgânicas, mas sobretudo, pelas conseqüências psicossociais, especialmente o relacionamento que se estabelece entre os deficientes e os demais.

Até a década de 70, as deficiências eram definidas e classificadas de acordo com o modelo médico, considerando a tríade: etiologia/patologia/manifestaçōes. A IX Assembléia da Organização Mundial de Saúde, apresentou uma nova conceituação, publicada na Classificação Internacional de Deficiências, Incapacidades e Desvantagens (PORTUGAL, 1989).

Por este sistema são conceituados:

\section{Deficiência}

Perda ou anormalidade de estrutura ou função psicológica, fisiológica ou anatômica, temporária ou permanente. 


\section{Incapacidade}

Restrição resultante de uma deficiência da habilidade para desempenhar uma atividade considerada normal para o ser humano.

\section{Desvantagem}

Prejuízo para o indivíduo decorrente de uma deficiência ou de uma incapacidade que limita ou impede o desempenho de papéis de acordo com a idade, sexo, fatores sociais e culturais.

A desvantagem relaciona-se às dificuldades nas habilidades de sobrevivência - orientação, independência física, mobilidade, atividades da vida diária, capacidade ocupacional e integração social. No Brasil, este conceito tem sido levado em conta na concessão de benefícios sociais.

De acordo com Amiralian e colaboradores (2000), a integração entre os conceitos, com relação aos níveis de manifestação, pode ser esquematizada como:

\section{Doença}

Distúrbio

ou $\longrightarrow$ Deficiência $\longrightarrow$ Incapacidade $\longrightarrow$ Desvantagem

Os autores observam, entretanto, que uma pessoa pode ter uma deficiência sem incapacidade, uma incapacidade sem desvantagem, ou mesmo uma desvantagem sem incapacidade ou deficiência.

A deficiência mental é um distúrbio global de desenvolvimento freqüente, que atinge cerca de 10\% dos brasileiros.

Segundo a descrição do DSM-IV (2002) a característica essencial do retardo intelectual é apresentar um funcionamento intelectual significantemente inferior a média, com manifestações an- 
teriores aos 18 anos e limitações associadas a 2 ou mais áreas de habilidades adaptativas, tais como: comunicação, cuidados pessoais, atividades acadêmicas, saúde, lazer e trabalho. Esta também é a definição de deficiência mental (DM) adotada pela Associação Americana de Retardo Mental (AAMR,1992). O funcionamento acadêmico geralmente é definido pelo coeficiente de inteligência (QI ou equivalente), avaliado por testes como: Escala de Inteligência para Crianças de Wechsler-Revisto, Stanford Binet, Bateria de Avaliação Infantil de Kaufman, entre outros.

O quociente médio de inteligência é 100 e aceita-se como desvio-padrão dessa média o valor 15. O funcionamento intelectual significantemente inferior à média, é definido com um QI de 70 ou abaixo, em resultados obtidos da realização de um teste individual de QI. Em função da severidade, a OMS (1968) recomenda a subclassificação do Retardo Mental (RM) em: Leve: QI 70 - 50; Moderado: QI 50 - 35; Severo: QI 35 - 20; Profundo: QI abaixo de 20.

Enquanto que no Sistema 1992 da Associação Americana de Retardo Mental era observado o valor do QI como critério de demarcação da avaliação intelectual, o Sistema 2002 considera como ponto de definição, a ocorrência de dois desvios padrões abaixo da média, em testes padronizados para a população considerada (CARVALHO; MACIEL, 2003).

A AAMR, (2002) leva também em consideração os Padrōes e Intensidade dos Apoios Necessários, a saber:

\section{Intermitente}

Apoio apenas quando necessário, podendo ser de baixa ou alta intensidade, por exemplo, na fase aguda de uma doença. 


\section{Limitado}

Apoio intensivo caracterizado por sua duração contínua, por tempo limitado mas não intermitente. Por exemplo, apoios transitórios durante o período escolar e a vida adulta.

\section{Extenso}

Regularidade diária de apoio em alguma área de atuação, como na vida familiar, social ou profissional.

\section{Generalizado}

Apoio constante e intenso, necessário em diferentes áreas de atividade da vida.

Turk (2003) observa que este sistema de apoio, torna o diagnóstico significativo, com a identificação de limitações pessoais que permitem desenvolver um perfil de apoios necessários.

Em junho de 2006, os membros da AAMR votaram pela mudança do nome para "Associação Americana de Desabilidades Intelectuais e do Desenvolvimento", seguindo a tendência da Organização Mundial de Saúde que substituiu o termo "retardo mental" por desabilidade intelectual que no Brasil corresponde à deficiência intelectual (DI). Acredita-se que as estimativas do número de pessoas com DI tenham relação com o grau de desenvolvimento do país, situando-se entre 4,6\% nos países pobres e 2,5\% nos mais desenvolvidos, segundo o Relatório da ONU de 2001 sobre doenças mentais referido em PsiqWeb.

Os fatores etiológicos podem ser biológicos, psicossociais ou uma combinação de ambos. Em cerca de 40\% dos casos, esses fatores podem ser identificados na avaliação clínica e genética 
mas na maioria (60\%), não se pode determinar uma etiologia clara, sendo classificados como idiopáticos. A categoria de retardamento leve é a mais freqüente e apresenta-se muitas vezes associada a influências ambientais como problemas de gravidez e perinatais, exemplificadas por má qualidade da nutrição fetal, prematuridade, problemas de oxigenação, infecçōes, traumas. Casos de deficiência intelectual, devido a fatores biológicos conhecidos tais como a síndrome de Down ou a síndrome do Xfrágil, apresentam uma prevalência semelhante em crianças das diferentes classes sócio-econômicas.

A idade em que a criança é diagnosticada depende, muitas vezes, do nível de gravidade dos déficits apresentados e da ocorrência de traços fenotípicos característicos. O diagnóstico e a intervenção terapêutica precoces são condiçōes essenciais para um bom prognóstico do desenvolvimento da criança. 



\section{"São precisamente as alterações da natureza pelos homens, e não a natureza enquanto tal que constitui a base mais essencial e imediata do pensamento humano"}

Frederich Engels. 1978. 



\section{4}

\section{O papel dos pais e dos educadores na educação sexual da pessoa com deficiência intelectual}

No contexto social, o sexo e a sexualidade são considerados atributos restritos a indivíduos adultos e saudáveis. As manifestações da pessoa com deficiência intelectual são freqüentemente tidas como indesejáveis, exacerbadas ou até inexistentes, constituindo motivo de apreensão na família ou na escola.

Nessas pessoas, entretanto, geralmente o desenvolvimento anatômico e fisiológico não é comprometido e, as diferenças observadas no comportamento sexual devem-se a aspectos relacionados à capacidade cognitiva e adaptativa. São, portanto, pessoas sexuadas, que atuam e percebem a sua sexualidade dentro da etapa de maturidade psicossocial que tenham alcançado.

A sexualidade é essencial para a vida do indivíduo e pode ser expressa de várias maneiras, não apenas com o uso de órgãos genitais. O olhar, o toque, o beijo e o abraço são manifestaçōes de sexualidade e afetividade.

Muitos problemas advindos do desenvolvimento fisiológico e do comportamento da pessoa com deficiência intelectual podem ser evitados pela educação sexual. Para isto, é necessário o empe- 
nho da família no sentido de educar o indivíduo para viver de acordo com as convenções sociais. Cabe aos pais acompanhar cada nova etapa do desenvolvimento da criança, sem superproteção, atendendo às necessidades de orientação e limites, colocados sem autoritarismo, mas com firmeza e consistência.

Colocar limites é uma maneira positiva de ajudar a criança a crescer emocionalmente, aprendendo a controlar os seus impulsos e a discernir o que é permitido e proibido na vida social.

As pessoas com deficiência intelectual geralmente apresentam dificuldade de assimilar os limites e as regras sociais, o que requer paciência e interesse dos pais e educadores para ajudarem-nas a vencer essas dificuldades acentuadas pela falta de amigos e pelos preconceitos sociais. Os pais que não se sentirem seguros para tratar do assunto, devem procurar o apoio profissional, pois, de modo ideal, a educação sexual deve ser uma tarefa integrada da família e dos educadores.

Segundo Vygotsky (1984), a aprendizagem é fundamental para o desenvolvimento do ser humano, desde o seu nascimento. A construção de novos conhecimentos é mediada pela linguagem (mediação semiótica). Os educadores assumem o papel de mediadores, possibilitando à criança a investigação do que lhe despertou a curiosidade.

Para mediar a tarefa de orientação ou educação sexual, é necessário que a pessoa tenha conhecimentos básicos e, principalmente, se sinta confortável com o tema, de modo que possa transmitir a idéia de sexualidade como algo agradável e gratificante, e não como uma atividade que deve ser reprimida e censurada (MOREIRA, 1990).

A educação sexual na escola, do ponto de vista didático, requer a escolha de conteúdos básicos. Os Parâmetros Curriculares Nacionais (PCN) (MEC, 2000) organizam os conteúdos em 3 blocos principais:

\section{4}


- Corpo: matriz da sexualidade.

- Relações de gênero

- Prevenção às Doenças Sexualmente Transmissíveis / AIDS.

Segundo os critérios de avaliação do PCN espera-se que o aluno:

- Conheça as características e transformações de seu próprio corpo e do outro sexo.

- Aja sem descriminação na relação com as pessoas de ambos os sexos não depreciando atitudes e formas de expressão assumidas por pessoas do outro sexo.

- Conheça as diferenças de atribuição e expectativas em relação ao homem e a mulher, ao longo da história,em diferentes sociedades.

- Tenha as informações básicas e corretas sobre as doenças sexualmente transimissíveis e desenvolva atitudes de respeito e solidariedade em relação as pessoas portadoras do HIV ou doentes de AIDS. 

"Toda a pessoa tem dignidade e valor próprio. A sexualidade faz parte da vida de todas as pessoas.

A sexualidade inclui dimensões biológicas, éticas, espirituais. psicológicas e culturais. Os individuos expressam sua sexualidade de várias formas. O exercício da sexualidade compreende aprender o respeito ao corpo. aos próprios sentimentos e aos do outro."

Fórum Nacional de Educação e Sexualidade. 1994. 



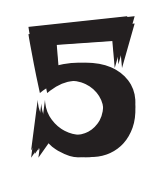

\title{
Questionamentos sobre a sexualidade da pessoa com deficiência intelectual
}

\begin{abstract}
O tema "Sexualidade e Deficiência Intelectual" reúne duas situações em que ainda persistem dúvidas e preconceitos, não apenas por parte de pessoas leigas, mas também entre os profissionais.

Aqui são relacionadas algumas questões freqüentemente formuladas em programas educativos:
\end{abstract}

\section{A pessoa com deficiência intelectual pode apresentar comportamento sexual?}

Na ausência de malformações severas, esta pessoa atua e percebe a sua sexualidade dentro da etapa de maturidade psicossocial alcançada. O desenvolvimento físico na adolescência leva naturalmente, a novos comportamentos e à manifestação do interesse sexual. Torna-se então mais urgente a educação sexual, que, de modo ideal, deveria ser conduzida pela família e pela escola.

\section{Qual é o papel dos pais e dos professores na educação sexual?}

Os pais devem começar cedo a educação sexual da crian 
ça, respondendo as suas dúvidas e orientando o seu comportamento, dentro dos parâmetros sociais vigentes. Os professores, além de orientar e informar, podem servir de modelos adequados de interaçōes sociais, fora do âmbito da família.

\section{A manipulação dos genitais freqüentemente} observada em pessoas com deficiência intelectual severa, pode significar manifestação de desejo sexual? Considerando que o desejo sexual está relacionado ao desenvolvimento psicossexual e cognitivo, acredita-se que esta função esteja mais limitada em pessoas com déficits severos sem, contudo, estar anulada. A puberdade, com a carga de hormônios decorrentes do desenvolvimento fisiológico, pode ser um fator de estímulo para a expressão de manifestações sexuais, assim como o prazer decorrente do toque.

\section{Como lidar com o tema masturbação?}

A masturbação provoca sensaçōes prazerosas e, realizada de modo adequado, contribui para o bem-estar do indivíduo. Cabe, geralmente, aos pais, a orientação de que esta é uma atividade privada, que não deve ser praticada em público e, quando necessário, como proceder para não se machucar.

\section{Como se comportar com pessoas que apresentam masturbação compulsiva?}

Inicialmente deve ser entendido que a masturbação é uma experiência natural que proporciona o autoconhecimento do corpo e a descoberta de sensações prazerosas. O toque no pênis pelo menino e no clitóris, pela menina pode 
ocorrer desde a tenra infância. Entretanto passa a constituir um problema quando é excessiva, prejudicando as outras atividades ou quando é realizada em locais e momentos inadequados. Neste caso, a repressão do comportamento e a orientação devem ser feitas com firmeza e esclarecido os limites que a sociedade estabelece na realização desta prática.

\section{Como orientar os pais ou a pessoa com deficiência sobre poluçōes noturnas?}

Deve-se esclarecer que é um fenômeno que ocorre naturalmente e que é mais freqüente quando o rapaz não tem relaçōes sexuais ou não se masturba, não ejaculando, portanto. Observar que acontece também em outros indivíduos sem deficiência mental, com vida sexual pouco ativa.

\section{Como orientar situações de namoro, relações sexuais e esterilização?}

O namoro é conseqüência do apaixonamento, que pode ocorrer entre pessoas com deficiência intelectual. Deve haver diálogo, orientação sexual, e devem ser tomadas medidas preventivas para evitar a gravidez indesejada. É necessário que haja uma boa compreensão das regras sociais e atenção aos limites. Caso a pessoa venha a se casar, o apoio da família é muito importante e não deve ser esquecido o aconselhamento genético no caso de deficiência por causa genética.

A esterilização pode constituir-se em uma medida necessária em alguns casos. Esta decisão a requer orientação de profissionais especializados e, não deve prescindir do apoio psicológico à pessoa com deficiência 
e a sua família. Não deve, entretanto, ser esquecido que mesmo submetido à esterilização, o indivíduo continua um ser sexuado com emoçōes e direitos a vivenciar experiências sexuais gratificantes.

\section{8. É correto propiciar ao filho com deficiência intelectual encontros com prostitutas?}

A questão é válida para filhos com deficiência ou não, e, uma decisão a este respeito, depende do ponto de vista pessoal dos pais. É importante também considerar que, ao invés de serem encorajados a ter uma relação sexual ocasional, filhos e filhas com deficiência podem ser apoiados em um namoro que possa evoluir para um relacionamento sexual pleno. Segundo Gauderer (1996), a experiência mostra que rapazes que tiveram uma iniciação sexual dessa forma tendem a ver a mulher como mercadoria de consumo. Além disso, pode tornar-se incompreensível para o jovem com deficiência o fato de que com algumas mulheres seja permitido ter relaçōes sexuais e não com todas, podendo isto gerar situaçōes constrangedoras.

\section{Pessoas com Síndrome de Down (SD) podem ter filhos?}

A esterilidade tem sido constatada em muitos homens com S. Down. Há, entretanto, descrição na literatura de raros casos de reprodução, recomendando-se assim a realização de exames de fertilidade em situações de planejamento reprodutivo ou escolha de medidas contraceptivas definitivas como a vasectomia. Quanto à mulher com SD, sua fertilidade nem sempre é diminuída e geralmente apresenta 50\% de possibilidades de ter filhos normais e a 
mesma probabilidade de filhos com a síndrome. Para maiores esclarecimentos, consultar o artigo de Moreira e Gusmão (2002).

\section{Casal que tem deficiência intelectual não associada a síndromes terá filhos normais ou também deficientes?}

Não há dúvida que há um componente hereditário importante na inteligência. Na maioria dos casos, trata-se de alteração condicionada por muitos genes, cuja expressão é influenciada por fatores ambientais. Quando o casal apresenta deficiência intelectual leve, a probabilidade de nascer um filho com a mesma afecção situa-se em torno de 42\% (FROTA-PESSOA, 1983). Pode contribuir para este percentual não apenas o conjunto de poligenes, mas, também, causas ambientais desfavoráveis, como a privação psicossocial, desnutrição e outras conseqüências de pobreza.

Nos casos em que a deficiência decorre de fatores ambientais (infecçōes intra-uterinas ou pós-natais, ação de substâncias tóxicas, sofrimento fetal, traumatismo do parto), o risco é o mesmo que o de casais normais, exceto quando existem condições ambientais desfavoráveis à criação de um filho.

\section{Como prevenir o abuso sexual?}

O abuso sexual é, infelizmente, uma prática criminosa freqüente na sociedade, em que ocorre relação sexual sem consentimento, por coerção física ou emocional. Na maioria das vezes, é realizada por agressores conhecidos e familiares à criança, determinando conseqüências graves em termos de lesões físicas, infecçōes, gravidez indesejada 
ou seqüelas emocionais. Podem contribuir para a sua prevenção uma boa educação sexual, dada em casa ou na escola, com ensinamentos do que é permitido e como se proteger em situaçōes de risco. É importante que haja na família uma relação de confiança e estímulo ao diálogo que facilite a comunicação imediata de ocorrências dessa natureza.

\section{Dica para os pais:}

Demonstre o seu amor sem superproteção. Coloque limites sem autoritarismo mas com firmeza: colocar limites é uma maneira positiva de ajudar a criança a crescer emocionalmente, aprendendo a controlar os impulsos e a adquirir as regras de convívio na vida social, aprendendo o que é considerado correto e o que não é aceito. 


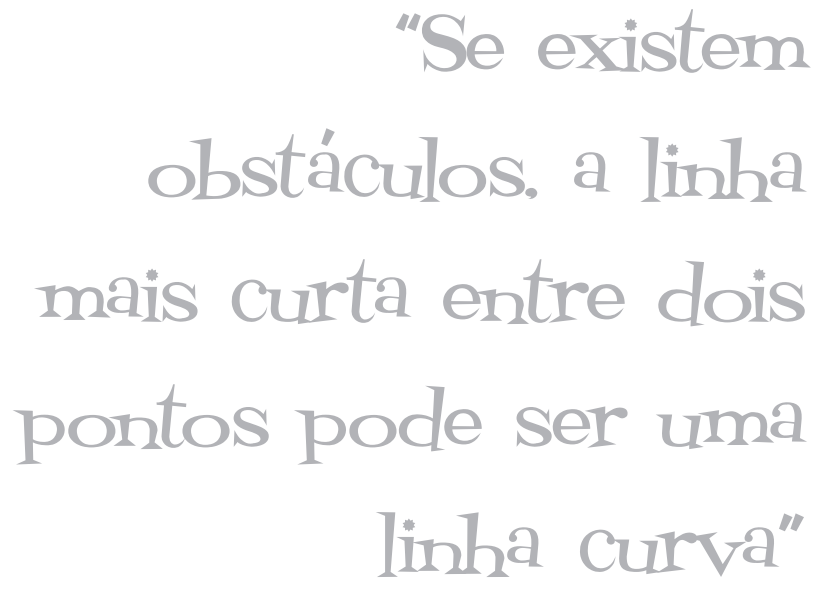

Bertold Brecht (1898 - 1956) 



\section{6 \\ Dinâmicas de grupo \\ e oficinas}

O papel do professor e do orientador escolar na educação sexual da pessoa com deficiência intelectual não tem sido suficientemente incentivado e desenvolvido. Contribui para esta situação a falta de material didático adequado. Uma revisão das publicações na área de saúde realizada por Bastos e Deslandes (2005) através da Biblioteca Virtual Bireme, utilizando como palavras chaves: deficiência, retardo mental, adolescência e sexualidade, teve acesso a apenas 21 artigos que tratavam de temas como: sexualidade, contracepção, esterilização, abuso sexual e repercussões familiares e psicossociais. Entretanto, embora o número de publicaçōes e pesquisas científicas sobre o tema tenha aumentado, há ainda poucos relatos de programas pedagógicos de educação sexual.

Glat e Freitas (1996) descrevem a aplicação de grupos operativos na educação sexual de 30 pessoas com deficiência intelectual com certo grau de compreensão verbal e maturidade social. De acordo com a metodologia, o coordenador selecionava tópicos para a discussão que ocorria livremente. Posteriormente, eram acrescentados outros recursos à proposta, como apresentação de desenhos, gravuras e pesquisas e elaboração de cartazes. 
Camargo e Ribeiro(1999) abordam a sexualidade como tema transversal na educação infantil e apresentam uma proposta metodológica em que o professor tem o papel do mediador.

Por exemplo, o estudo da questão: Como nascem os bebês? é desenvolvido em uma perspectiva de educação integral, incluindo no aprendizado conhecimentos de Matemática, Música, espaço, tempo, sexualidade.

O programa apresentado neste livro reúne oficinas pedagógicas e dinâmicas de grupo, originais ou adaptadas de experiências educacionais regulares como as descritas em Cavalcanti (1992); Serrão e Baleeiro (1991); Yozo (1996) em que o trabalho com o corpo é valorizado e a verbalização nem sempre é essencial.

As atividades são realizadas em um tempo delimitado, com objetivos, procedimentos e material previamente estabelecidos.

A música é utilizada em quase todas as oficinas, de preferência instrumental, estilo new age, mantras indianos ou músicas clássicas. Para o "aquecimento" do grupo, são aplicadas, no início do trabalho, diferentes dinâmicas de apresentação, movimento e jogos lúdicos.

O número ideal de participantes situa-se entre dez e quinze. É essencial o respeito ao indivíduo, às diferenças e ao seu desejo de participar ou não do programa.

As atividades utilizam como material pedagógico, papel, cartolina, canetas hidrográficas, sucata em geral, que deve ser preparado com antecedência, evitando assim, problemas e atraso do desenvolvimento do trabalho.

Considerando as dificuldades decorrentes dos déficits apresentados pelos participantes, deve ser priorizado um processo eficiente de comunicação que aprenda a escutar e a desenvolver outras formas positivas de comunicação.

Confira as 13 oficinas inclusivas nas páginas seguintes.

\section{8}




\section{1 \\ QUEBRANDO BARREIRAS NO RELACIONAMENTO SOCIAL}

Colaboração: Mariana de O. Rodrigues ${ }^{1}$

\section{Objetivo:}

* Contribuir para a interação dos estudantes e profissionais da escola.

\section{Material:}

* Gravador, fitas de relaxamento com música suave, espaço físico amplo.

\section{Tempo:}

* 60 minutos.

\section{Procedimento:}

Este modelo de oficina, comum em programas pedagógicos, é indicado como atividade inicial de trabalhos educativos em escola inclusiva. Devem ser convidados para participar da atividade alunos, professores e outros profissionais. O número de participantes deve ser estabelecido a depender do espaço oferecido para a realização da atividade.

De início, o oficineiro deve apresentar a equipe de trabalho. A seguir colocar uma música suave e solicitar que os participantes movimentem-se na sala e cumprimentem os colegas que não conhecem ou com quem não tem intimidade.

\footnotetext{
${ }^{1}$ Estudante de graduação em Ciências Biológiicas - UFBA.
} 
Ao término desta fase de abertura dos trabalhos, propor aos participantes a realização de uma das duas dinâmicas descritas abaixo.

\section{Opção 1:}

* Formar um círculo com os participantes.

* Dar início à dinâmica esclarecendo a importância de uma convivência harmoniosa no ambiente escolar. Abrir espaço para a aproximação entre os participantes, dizendo a frase "Se você me conhecesse, saberia que"... acrescentando ao final desta frase um fato ou característica pessoal importante que a maioria das pessoas não sabe e que não signifique uma invasão à sua privacidade.

* Pedir que cada participante repita a frase, completandoa com algo que julgue relevante e que favoreça o conhecimento e aceitação das pessoas no grupo.

\section{Opção 2:}

* Estabelecer uma linha divisória, na área de realização do trabalho, com todos os participantes reunidos em um dos dois lados. Demarcar a linha divisória com giz ou barbante.

* Iniciar a dinâmica com declarações que possam demonstrar que são comuns as diferenças entre pessoas em diversos aspectos como gosto, temperamento e preferências. Em seguida abrir espaço para uma reflexão sobre os preconceitos que podem acompanhar a diversidade, com frases como: "Se você já se sentiu descriminado, atravesse a linha..."; "Se você já se achou incompreendido na sua família, na sua escola, por seus amigos, atravesse a linha..."; "Se você não está satisfeito com alguma coisa na sua aparência, atravesse a linha..."; "Se você se sente tímida ou insegura, atravesse a linha...".

\section{0}


* Ao término de cada desafio, abrir espaço para depoimentos. Acolher gestos espontâneos como aplausos, abraços ou aproximação entre os participantes.

\section{Conclusão:}

* Encerrar a oficina comentando que todas as pessoas têm diferenças e dificuldades que, muitas vezes, não são percebidas pelos outros e que todos, indistintamente do sexo, idade e de outras diferenças, precisam de compreensão, carinho e consideração. 


\section{2 \\ CONVERSANDO COM OS PAIS: EXPECTATIVAS SOBRE A EDUCAÇÃO SEXUAL}

\section{Objetivos:}

* Constatar que as experiências vivenciadas por cada pessoa determinam seu posicionamento sobre a sexualidade.

* Identificar diferentes relacionamentos.

* Levar os participantes a refletir sobre a importância da educação sexual na estrutura da personalidade e comportamento do indivíduo.

\section{Material:}

* Folhas de papel, lápis ou caneta, papel metro, quadro.

\section{Tempo:}

* 60-90 minutos

\section{Procedimento:}

* O (a) coordenador (a) se apresenta aos participantes e expōe objetivamente a proposta de realizar atividades de educação sexual na escola, caracterizando os objetivos e a metodologia. Deve ser enfatizado que se trata de trabalho conjunto da escola e da família, que complementará as informaçōes com seus valores e sentimentos.

* Após a explanação inicial, o (a) coordenador (a) dará oportunidade para questionamentos e colocações. A seguir, apresentará ao grupo três questōes e problemas para serem respondidas individualmente em folha de papel: 
- Como foi a minha educação sexual?

- Que educação sexual desejo para o meu filho?

- Quero que meu filho participe deste programa?

* Após recolher as respostas que servirão de subsídio para o curso, incentivar o debate, reconhecendo as diferenças individuais e valorizando a colaboração dos pais na educação global dos filhos. 


\section{3 \\ REFLEXÃO SOBRE A EDUCAÇÃO SEXUAL DOS PAIS E EDUCADORES}

\section{Objetivos:}

* Propiciar a análise de valores sobre a sexualidade.

* Reciclar conhecimentos sobre temas como saúde reprodutiva, namoro, casamento e deficiência intelectual.

Tempo:

* 60 - 90 minutos

\section{Procedimento:}

Sondagem de valores e atitudes sobre a sexualidade, com a dinâmica "discordo/concordo". Distribuir quadrados de cartolina verde e vermelha para os participantes que devem levanta-los diante de afirmação com os quais concordem (verde) ou discordem (vermelho). Anotar os resultados de cada manifestação, frente a uma série de afirmações.

* A educação sexual não é necessária.

* Os jovens de hoje sabem mais sobre relacionamento sexual do que os de antigamente.

* A menstruação é uma necessidade do organismo principalmente para o adolescente.

* A pessoa com deficiência intelectual pode masturbar-se desde que faça de modo reservado, em particular.

* A pessoa com deficiência geralmente não tem interesse sexual

* A pessoa com deficiência tem desejos e sentimentos sexuais.

* A sexualidade é uma parte natural e maravilhosa do ser humano e todos tem direito a ela. 
* A falta de informação sobre a sexualidade leva a problemas.

* A pessoa com deficiência intelectual é sempre uma criança.

* Os anticoncepcionais injetáveis constituem métodos eficientes de controle de natalidade para jovens com deficiência mental.

* O sexo - procriação é mais importante do que o sexo recreação.

* A falta de diálogo leva ao desenvolvimento sexual inadequado.

Após a leitura das frases e registro das respostas, incentivar o debate perguntando aos participantes:

* Como se sentiram nesta atividade?

* Porque nem todos pensam do mesmo jeito?

* Por que é tão difícil nos posicionarmos contra a maioria?

Abrir espaço para questionamentos. Encerrar a discussão reconhecendo a diversidade de pensamentos e opiniōes, que é resultado da história de vida de cada um e também a importância de que se conheça o próprio posicionamento e sentimentos sobre o tema e principalmente, que se esteja disposto a se atualizar para orientar corretamente os filhos. 


\section{4 \\ UM OLHAR SOBRE A PESSOA COM DEFICIÊNCIA \\ Colaboração: Mariana de O. Rodrigues ${ }^{1}$}

\section{Objetivos:}

* Incluir pessoas com dificuldades no relacionamento social, incentivando o diálogo

* Estimular o desenvolvimento da auto-estima

* Identificar dificuldades de cognição do participante Material:

* Papel metro, cartolina, papel de ofício; figuras de revistas, cola, giz de cera, espelho.

\section{Tempo:}

* 30 a 60 minutos

\section{Procedimento:}

* Trata-se de uma atividade individual, a ser realizada por um (a) condutor (a) e o aluno (a). O primeiro passo é procurar um lugar calmo, sem muito fluxo de pessoas, onde possam sentar-se e conversar. Então a comunicação deve ocorrer de acordo com a reação do participante.

* Dica: pode-se começar com uma apresentação, explicando que o motivo da conversa é conhecê-lo melhor.

* A seguir, podem ser mostradas figuras, cores, objetos, perguntando do qual ele (a) gosta ou do que não gosta, pedindo que cole no papel as que selecionar.

* Fazer perguntas para avaliar as dificuldades de cognição como: que cor é essa, ou solicitar que indique determinada cor em um conjunto de lápis; trabalhar com figuras humanas solicitando que diferencie quem é homem de

Estudante de graduaçāo em Ciências Biológicas - UFBA. 
quem é mulher, diferenciar também crianças de adultos e de idosos.

* Trabalhar noção de lógica como quantidade, operaçōes matemáticas.

* Posicionar-se ao lado da pessoa no espelho e perguntar quem é ela e quem é você na imagem.

* Esse trabalho depende muito da criatividade do oficineiro que deve entender a individualidade da pessoa, esforçandose para estabelecer uma forma de comunicação e criar um clima de confiança e amizade com o participante. 


\section{5 \\ SONDAGEM DE ATITUDES EM RELAÇÃO À SEXUALIDADE E EDUCAÇÃO SEXUAL}

\section{Objetivos:}

* Verificar atitudes dos alunos quanto à situações que possam estar relacionadas à sexualidade.

* Oferecer aos alunos oportunidade de se posicionarem em relação a assuntos a serem tratados nas diferentes atividades de educação sexual.

* Identificar situações de dificuldades específicas que possam ser abordadas no programa.

\section{Material:}

* Fichas de observações a serem preenchidas pelo coordenador (a) ou monitor (es).

\section{Tempo:}

* 30 minutos por entrevista.

\section{Procedimento:}

* São realizadas entrevistas individuais com os alunos, de caráter informal, onde são feitos questionamentos relativos à sua auto-imagem como homem ou mulher, sentimentos, repressão ou incentivos na família, compreensão do meio ambiente, comportamento sexual, curiosidade sobre o tema e desejo de participar das atividades a serem desenvolvidas.

* Na entrevista são feitas as seguintes solicitações e questionamentos: 
1. Nome e idade

2. Desenhe um homem.

3. Desenhe uma mulher.

4. Desenhe você.

5. Desenhe seus pais.

6. O que você mais aprecia e valoriza no seu próprio sexo e no outro sexo?

7. Você assiste a programas de televisão? Caso afirmativo qual programa (ou qual tipo de programa) é o de sua preferência?

8. Você assiste novelas ou filmes de amor?

9. Os seus pais Ihe proíbem de assistir a esses programas? Caso positivo, por quê? O que você acha disso?

10. Você namora?

11. Como é seu namoro?

12. Caso você ainda não tenha alguém, você gostaria de encontrar uma pessoa para namorar? 13. Você gostaria de ter aulas de educação sexual na escola?

14. Sobre que assuntos deveriam ser as aulas?

Por quê?

15. Observações 


\section{6 \\ CONHECENDO E SENTINDO O SEU CORPO}

\section{Objetivos:}

* Levar os alunos a:

- Perceber as partes do seu corpo.

- Relaxar os sentidos.

- Sentir a integração das diferentes partes do corpo.

\section{Material:}

* Gravador, fitas de relaxamento com música suave, esteira ou tapete.

\section{Tempo:}

* 60 minutos.

Procedimento:

* Aliviar as tensōes do corpo sem verbalização. Andar em diferentes direçōes, movimentar as partes do corpo.

* Solicitar que cada aluno se sente num lugar da sala que vai ser o seu lugar.

* Deitar de forma cômoda. Fechar os olhos durante o início do trabalho.

* Adormecer todo o corpo, "desligando" as suas partes. Repousar. Colocar música suave. Ficar assim por algum tempo.

* Bem devagar e suavemente, despertar o corpo. O (a) coordenador (a) enumera as partes do corpo, vagarosamente, no sentido da cabeça aos pés.

* Sentar-se, tocar e olhar para o seu corpo, sentindo a forma e a textura. 
* Mover o corpo, estalar os dedos e alongar-se.

* Admirar o seu corpo, observar as partes que você mais gosta. Sentir-se bem consigo mesmo.

* Concluindo a atividade, o (a) coordenador (a) conversa com os alunos sobre o sentimento e as sensaçōes que foram despertados na atividade. 


\section{7 \\ SENSIBILIZANDO O CORPO}

\section{Objetivos:}

* Despertar no aluno o sentimento que o carinho e afeto fazem parte da sexualidade.

* Incentivar o desenvolvimento de atitudes de auto-estima e consideração com o outro.

* Relacionar o corpo ao afeto e ao amor.

\section{Material:}

* Gravador, fitas com músicas suaves ou mantras, esteiras ou tapetes.

\section{Tempo:}

* 60 minutos.

\section{Procedimento:}

* Solicitar que cada aluno se sente na sala, de preferência no mesmo lugar da atividade anterior. Possuir um espaço próprio lhe dará um sentimento de pertinência às atividades.

* Lembrar que o trabalho é uma continuidade do anterior. Sentar-se em posição cômoda e fechar os olhos. Encontrar-se consigo mesmo.

* Imaginar o seu corpo, lembrando o sentimento e as emoções da atividade anterior.

* Com voz pausada, o (a) coordenador (a) deve centrar a atenção no coração. Colocar a mão no coração, observando que ele, com seus batimentos, nos mantém vivos. Sentir o ritmo das batidas, acompanhando o seu pulsar. 
* Refletir que os nossos sentimentos e emoções parecem sair do nosso coração. O que faz este coração acelerar? Quem traz ao seu coração alegria e prazer?

* Lembre-se com carinho das pessoas que você gosta. Mentalize para elas muita harmonia e afeto.

* Lembre-se dos momentos felizes já vividos. Sinta saudades. Deixe o sentimento tomar conta do seu coração. * Pense neste momento que você está vivendo e sinta que você é capaz de receber e dar afeto, aos outros e a você mesmo.

* Concluindo a atividade, o (a) coordenador (a) conversa com os alunos sobre os cuidados com o corpo, como parte da auto-estima. 


\section{8 \\ DESCOBRINDO A SUA BELEZA}

\section{Objetivos:}

* Levar os alunos a reforçar a auto-estima

* Evidenciar valores comuns entre os estudantes

* Contribuir para o processo de inclusão

\section{Material:}

* Espelhos, pente, escova, fitas, presilhas, acessórios diversos de maquiagem incluindo lápis e delineador.

Tempo:

* 60-90 minutos

\section{Procedimento:}

* Esta atividade requer um número maior de monitores, de modo que cada um possa atender a dois alunos.

* Usando o espelho, conversar sobre a imagem e a beleza presente em todas as pessoas.

* Valorizar os pontos positivos na aparência do(a) aluno(a).

* Com uso do material disponível, fazer penteados, maquiagem e/ou tatuagens laváveis.

* Concluindo o processo de "embelezamento", mostrar como a pessoa ficou, com o uso do espelho.

* Conversar sobre a importância da valorização da imagem, do cuidar-se e de gostar-se. 


\section{9 \\ CARACTERIZANDO AS PARTES DO CORPO}

\section{Objetivos:}

* Levar os alunos a:

- Conhecer e identificar as partes do seu corpo.

- Relacionar as funçōes.

- Identificar os órgãos sexuais do homem e da mulher.

\section{Material:}

* Gravuras/ desenhos do corpo do homem e da mulher.

* Folhas de papel pardo ou cartolina.

* Pincéis atômicos de cores diversas (pelo menos dois para cada aluno)

* Fita colante.

\section{Tempo:}

* 90 minutos.

\section{Procedimento:}

* O (a) coordenador (a) faz uma breve explanação sobre o tema.

* Exposição dos cartazes com figuras do corpo humano.

* Distribuir uma folha de papel pardo e pincel atômico para cada grupo de quatro alunos

* Um (a) aluno (a) deita-se sobre o papel enquanto os outros traçam o seu contorno com o pincel atômico.

* Terminada a tarefa, afixar na parede os desenhos feitos e comparar aos cartazes previamente apresentados.

* Solicitar aos participantes que denominem as diferentes partes do corpo e as suas funçōes. Acrescentar e esclarecer conceitos e conhecimentos equivocados. 
* Dar início à discussão, dirigindo ao grupo questões como:

- Por que é difícil falar sobre as partes do corpo relacionadas à nossa atividade sexual?

- Porque é importante o respeito pelo nosso corpo e pelo corpo do outro?

* Encerrar a discussão com as considerações necessárias. 


\section{0 \\ DISCUTINDO O COMPORTAMENTO \\ SEXUAL DO ADOLESCENTE: \\ COMO EVITAR UMA GRAVIDEZ INDESEJADA}

\section{Objetivos:}

* Levar os educandos a:

- Compreender as transformaçōes no corpo e as etapas do desenvolvimento que indicam o início da adolescência.

- Refletir sobre o significado da sexualidade na adolescência.

- Compreender que a sexualidade deve ser vivenciada com responsabilidade.

\section{Material:}

* Material audiovisual: som, vídeo, fitas de vídeo, CD, DVD; cartazes sobre o aparelho genital masculino e feminino; mostruário dos métodos contraceptivos.

\section{Tempo:}

* 90 minutos.

\section{Procedimento:}

* Introduzir o tema com breve explanação sobre as transformaçōes que acompanham o desenvolvimento do indivíduo da infância, passando pela adolescência, até a fase adulta.

* Caracterizar a adolescência.

* Apresentar o tema utilizando recursos audiovisuais e interromper a apresentação, quando houver questionamentos.

* Discutir e orientar os alunos sobre os assuntos apresentados. 
Não sendo possível apresentar o material audiovisual, o (a) coordenador (a) pode realizar uma exposição de cartazes ilustrativos, mostruário dos métodos anticoncepcionais e relato de experiências, escutando e respondendo às dúvidas e aos questionamentos. Na atividade, é desenvolvido o princípio básico de que a sexualidade deve ser exercida com adequação e responsabilidade. 


\section{1 \\ SEXO E PRECONCEITOS: \\ IDENTIFICANDO E DISCUTINDO OS PAPÉIS SEXUAIS}

Objetivos:

* Levar os alunos a:

- Compreender as diferenças entre os gêneros do ponto de vista biológico, psicológico e social.

- Desenvolver atitudes de respeito com o seu próprio sexo e o outro.

\section{Material:}

* Folhas de papel pardo, revistas com gravuras (duas revistas para cada quatro alunos), cartazes e figuras em isopor de homens e mulheres, tesoura de cortar papel, novelo de lã, cola, fita adesiva.

\section{Tempo:}

* 90 minutos

\section{Procedimento:}

* Dividir a classe em pequenos grupos de quatro alunos. Cada grupo deverá preparar cartazes com colagens referentes à mulher e ao homem na época atual.

* Os grupos devem selecionar as gravuras de acordo com as características que consideram típicas do homem e da mulher.

* Cada grupo deverá indicar um relator que apresentará o trabalho realizado.

Ao final da atividade, o (a) coordenador (a) deverá fazer uma síntese do exposto, esclarecendo a impropriedade de preconceitos em relação a um ou outro sexo. 


\section{2 \\ DINÂMICA DE GRUPO PARA TRABALHAR TEMAS \\ DIVERSOS RELACIONADOS À SEXUALIDADE}

\section{Objetivos:}

* Levar o aluno a:

- Refletir sobre os temas apresentados.

- Realizar vivências que desenvolvam o seu potencial afetivo.

\section{Tempo:}

* 90 minutos.

\section{Procedimento:}

* Cada participante deve sentar-se integrando um círculo.

* O (a) coordenador (a) propõe a discussão do tema selecionado e esclarece o seu significado.

* Na conversa com o grupo, é estimulado o relato de problemas e experiências dos participantes.

* É feita a seleção de uma situação para ser dramatizada.

* Os personagens são escolhidos e, então, realizado o jogo dramático.

* Os papéis podem ser trocados, favorecendo a percepção de si mesmo e do outro.

* Todos devem ter oportunidade de participar do jogo dramático.

* Colocar o grupo sentado em círculo para finalização. Comentar a experiência. 


\section{3}

MODELO DE OFICINA UTILIZANDO O TEATRO DE BONECOS EM ATIVIDADES DE EDUCAÇÃO SEXUAL:

Colaboração: Adelina Rebouças ${ }^{1}$;Antonio de S. Batista ${ }^{2}$; Clarissa Lima

Falcão ${ }^{3}$; Mariana de O. Rodrigues ${ }^{4}$.

\section{Objetivos:}

* Oferecer uma visão mais ampla sobre o que é a sexualidade

* Identificar a opinião dos alunos a respeito dos temas propostos de acordo com as reações individuais.

* Propiciar a aprendizagem de novos conhecimentos através do lúdico.

Material:

* Aparelho de som

* CDs diversos

* Fantoches

* Armação para teatro de fantoches

\section{Procedimento:}

* Apresentação de dramatização em que bonecos tratam de temas diversos de sexualidade, conforme a peça.

* Os bonecos podem formular perguntas a platéia de modo a incluir todos na discussão do tema solicitado.

* Colocar música para encerramento.

\section{Comentários:}

* O teatro de bonecos, também denominados fantoches, marionetes ou mamulengos, constitui uma atividade lúdica

\footnotetext{
${ }^{1}$ Artista plástica e atriz; ${ }^{2}$ Biólogo e professor universitário; ${ }^{3}$ Bióloga e geneticista;

${ }^{4}$ Estudante de graduação em Ciências Biológicas - UFBA.
} 
muito apreciada por crianças e também pelos adultos.Os bonecos atuam como réplicas de seres humanos, animais ou outras formas, desenvolvendo a imaginação fazendo rir ou chorar, provocando emoçōes. Quando os fantoches apresentam situaçōes na dramatizaçāo, os ouvintes se identificam com os personagens e muitas vezes descobrem verdades por si próprias.

No Brasil, a apresentação de peças teatrais em escolas começou incentivada pelos movimentos de educação especial. Atualmente, constitui recurso didático utilizado em diferentes práticas educativas, podendo servir para passar mensagens adequadas, com a representação de situações e vivências diversas.

O trabalho com o Teatro de Bonecos se contrapõe à limitação do ensino tradicional considerado racional e exercita a criatividade e a imaginação. Vygotsky (1984) observa que

A imaģinação é um processo psicológico novo para a criança, representa uma forma especificamente humana de atividade consciente que não está presente na consciência das crianças muito pequenas. A situação imaginária de qualquer forma de brinquedo já contém regras de comportamento embora possa não ser um jogo com regras formais estabelecidas a priori. O que na vida real passa desapercebido pela criança, torna-se uma regra de comportamento no brinquedo. É no brinquedo que a criança aprende a agir numa esfera cognitiva. Sob o ponto de vista do desenvolvimento, a criação de uma situação imaginária pode ser considerada um meio para desenvolver o pensamento abstrato.

Esta linha de pensamento é também compartilhada por Piaget (1975) quando considera que a realização do jogo 
simbólico marca na criança a passagem da fase sensóriomotora para uma inteligência pré-operatória, com símbolos subjetivos.

O Teatro de Bonecos oferece excelente instrumento pedagógico e terapêutico, estimulando a construção do pensamento e a expressão verbal socializada. Facilita o desenvolvimento da fala, encoraja a enfrentar situaçōes difíceis, além de constituir espaço para a construção de idéias e espírito crítico.

A atividade com Teatro de Bonecos requer uma história, com diálogos curtos e poucos personagens; um palco e bonecos, que podem ser confeccionados como parte da atividade. O segredo dos bonecos está na movimentação e na linguagem que dão uma personalidade própria a cada personagem (RODRIGUES, 1990).

Os bonecos podem ser muito simples, formados de saquinhos de pipoca ou de sanduíches, com o rosto desenhado com canetas hidrográficas ou lápis de cor. Podem ser feitos também com retalhos de feltro colorido ou com massa de papel (papier maché), ou ainda ser adquiridos em lojas de brinquedos ou especializadas. A dramatização é executada em palco de madeira ou em espaço improvisado com caixa de papelão, colcha ou lona, colocados na altura necessária para cobrir o corpo dos manejadores dos bonecos. O palco mais simples é o improvisado com um lençol ou pedaços de panos presos a cadeiras, mesas ou árvores. Dependendo da história, é utilizado um fundo musical com músicas cantadas com a platéia, CD ou sons produzidos por instrumentos. 


\section{O Teatro de Bonecos na escola possibilita:}

* A compreensão de conteúdos específicos;

* A estimulação da expressão verbal e da criatividade;

* A dinamização do aprendizado.

\section{Orientações básicas:}

* As atividades podem compreender desde a preparação do boneco até a dramatização, ou então a representação de situaçōes ou vivências relacionadas ao desenvolvimento sexual, com bonecos prontos. O enredo pode ser proposto pelos alunos ou apresentado pelo coordenador. Pode ser solicitado aos participantes sugestões quanto a alguns pontos como nomes e características das personagens e dinâmica da apresentação.

* Nas peças criadas pelo grupo, o tema deve ser simples, sobre a sua realidade. Os diálogos devem ser curtos, acompanhados de movimentação dos bonecos. Sempre que possível, provocar o riso, criando situaçōes engraçadas e brincadeiras que não humilhem nem causem constrangimento e, sim, divirtam de modo positivo.

* O trabalho, como um todo, estimula no aluno o desenvolvimento da coordenação viso-motora, habilidades manuais, imaginação, autocrítica e socialização. Deve predominar o espírito de equipe, não apenas na divisão de tarefas que deve valorizar as habilidades individuais, assim como no reconhecimento e aceitação do outro.

* Em alguns casos, os bonecos podem ser manejados pelos alunos juntamente com os orientadores, que devem estimular a participação da platéia (Ex.: _ Vocês não acham?) e dar mensagens de confiança, ajuda e amizade. 
* No manejo do boneco, improvisar e utilizar o elemento fantasia. Na apresentação final dos atores para o público, não esquecer que o verdadeiro personagem é o boneco, elemento mágico que possibilita a comunicação (Figura 2).

* No encerramento da apresentação, os bonecos podem ser passados à platéia, criando um ambiente propício ao reconhecimento das personagens e a compreensão da mensagem educativa.

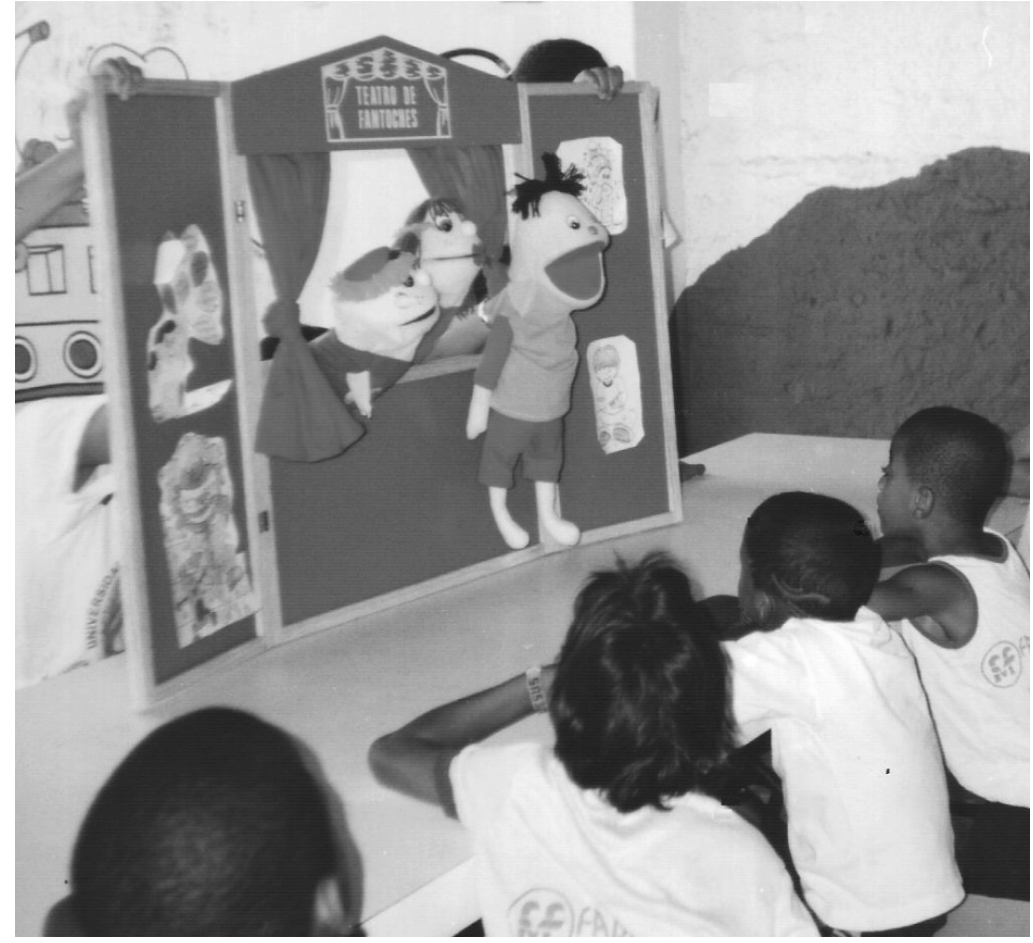

Figura 2 - Teatro de bonecos 

"Que pode uma criatura senão. entre criaturas amar? amar e esquecer amar e malamar amar, desamar, amar? sempre, e de ollhos vidrados. amar?"

Carlos Drummond de Andrade. 1992 



\title{
Aplicação do programa em diferentes instituições especializadas no estado da Bahia
}

\author{
Instituto Pestalozzi da Bahia \\ Colaboração: Ana Paula P. Gomes'1, Paola B. de Oliveira', Rodrigo F. de \\ Oliveira', Tereza C. C. Araújoº
}

Uma dificuldade freqüente apontada na estruturação de programas de Educação Sexual nas escolas é a falta de material didático adequado. Tendo em vista verificar a eficiência do roteiro de trabalho representado pelas atividades deste livro, estas foram aplicadas a alunos de escola especializada para pessoas com deficiência intelectual no Instituto Pestalozzi da Bahia. Esta escola apresenta dimensão de unidade social principal na vida dos alunos, que compartilham entre si, o estigma social da deficiência.

O grupo de alunos selecionados foi caracterizado como de classe sócio-econômica média ou média-baixa, de acordo com o local de residência, profissão e rendimento dos familiares. 
Os alunos freqüentavam a instituição nos turnos matutino ou vespertino, com atividades distribuídas em escolaridade e oficinas de treinamento profissional, com maior concentração de uma ou outra, a depender do déficit apresentado, analisado de acordo com os estágios de desenvolvimento de Piaget.

A conversa com os pais (Atividade 2) foi essencial para o estabelecimento da proposta e definição dos alunos que iriam vivenciar o programa de educação sexual. Assim, com o prévio consentimento dos pais, participaram do programa 13 alunas e 09 alunos, dos turnos matutino e vespertino, indicados pela escola.

Anteriormente às atividades didáticas e oficinas, foi feita uma sondagem com os estudantes para avaliação do nível de conhecimento sobre o sexo e a sexualidade e ajuste da programação. Os resultados obtidos com a análise de algumas das questōes colocadas são apresentados na Tabela1.

Deve ser ressaltado que devido às diferenças na deficiência intelectual dos estudantes, para alguns a temática não parecia ter significado maior, sendo neste caso necessário utilizar linguagem simples e diferentes formas de comunicação.

A percepção das diferenças sexuais foi analisada através da produção gráfica, obtida mediante solicitação do (a) entrevistador (a), de desenho de figuras sexuadas (homem, mulher, você, pai, mãe).

Mèridieu (1987) considera a linguagem gráfica como um modo de expressão própria da criança. Embora o valor semiótico das figuras seja analisado com cautela, levando em conta o contexto em que é elaborado, a produção de uma linguagem gráfica própria é desenvolvida em paralelo à evolução psicomotora da criança. A autora afirma que o grafismo começa pelo rabisco, gesto essencialmente motor e distingue as etapas evolutivas do grafismo infantil, de acordo com a terminologia de Luquet, na classificação que segue:

\section{0}




\section{Realismo fortuito}

Estágio iniciado em torno dos 2 anos, finalizando o período do rabisco. A criança que começava o seu traçado sem desejo de representação, descobre por acaso uma analogia entre um objeto e seu traçado e, retrospectivamente, dá um nome ao seu desenho.

\section{Realismo fracassado}

Fase iniciada geralmente entre 3 e 4 anos em que a criança, após a descoberta da identidade forma-objeto, procura reproduzir essa forma com fracassos e sucessos parciais .

\section{Realismo intelectual}

Período entre os 4 e os 10 ou 12 anos que se caracteriza pela criança desenhar o que sabe do objeto, utilizando recursos como a transparência ou a representação simultânea do objeto e do conteúdo, como exemplificada pelo bebê desenhado em transparência dentro do ventre materno.

\section{Realismo visual}

Ocorre por volta dos 12 anos com desenho infantil tornando-se impregnado pelas descobertas das perspectivas, empobrecimento do grafismo, levando às produçōes adultas.

A análise da produção gráfica obtida dos alunos mostrou que alguns jovens apresentaram grafismo rudimentar, sem tipificação sexual (Figura 3), enquanto que outros especificaram realismo intelectual e até visual (Figuras 4 e 5), demonstrando a diferenciação do grupo, independentemente da idade cronológica. Os desenhos foram analisados, tendo em vista o conhecimento de cada aluno e a formação do grupo, sem preocupaçōes semiológicas. 


\begin{tabular}{|c|c|c|c|c|c|c|c|c|}
\hline \multirow[t]{2}{*}{ OPINIŌES E ATITUDES } & \multicolumn{4}{|c|}{ CONCORDÃNCIA } & \multicolumn{4}{|c|}{ DISCORDÃNCIA } \\
\hline & $\mathrm{F}$ & $(\%)$ & M & (\%) & $\mathrm{F}$ & (\%) & M & (\%) \\
\hline $\begin{array}{l}\text { 1. Gosta do gênero ao } \\
\text { qual pertence? }\end{array}$ & 14 & $(82.40)$ & 19 & $(90,48)$ & 03 & $(17,6)$ & 02 & $(09,52)$ \\
\hline $\begin{array}{l}\text { 2. Aprecia e assiste } \\
\text { filmes e novelas } \\
\text { de amor? }\end{array}$ & 15 & $(88,20)$ & 17 & $(81,00)$ & 02 & $(11,80)$ & 04 & $(19,00)$ \\
\hline $\begin{array}{l}\text { 3.Não tem permissão } \\
\text { para assistir a esses } \\
\text { programas? }\end{array}$ & 02 & $(11,80)$ & 04 & $(19.04)$ & 15 & $(88,20)$ & 17 & $(80,96)$ \\
\hline 4. Tem namorado(a)? & 13 & $(76,50)$ & 16 & $(76,20)$ & 04 & $(23,50)$ & 05 & $(23.80)$ \\
\hline $\begin{array}{l}\text { 5. Tem relaciona- } \\
\text { mento sexual? }\end{array}$ & 03 & $(23.07)$ & 05 & $(50,00)$ & 10 & $(75,93)$ & 08 & $(50,00)$ \\
\hline $\begin{array}{l}\text { 6. Gostaria de ter } \\
\text { aulas de educação } \\
\text { sexual? }\end{array}$ & 13 & $(76,50)$ & 18 & $(85,70)$ & 04 & $(23.50)$ & 03 & $(14,30)$ \\
\hline 7. Temas para aulas: & & & & & & & & \\
\hline Conhecimento do corpo & 01 & $(05,90)$ & & & 01 & $(05,55)$ & & \\
\hline Namoro e casamento & 03 & $(17,65)$ & & & 06 & $(33,33)$ & & \\
\hline Métodos anticoncepcionais & 03 & $(17,05)$ & & & 03 & $(16,66)$ & & \\
\hline Outros & 06 & $(35,30)$ & & & 08 & $(44,44)$ & & \\
\hline
\end{tabular}

Tabela 1 - Opiniōes e atitudes dos alunos da escola especial sobre assunto relacionado à sexualidade e escolha de temas para aulas de educação sexual. F e $M$ : número de indivíduos dos sexos feminino e masculino. 

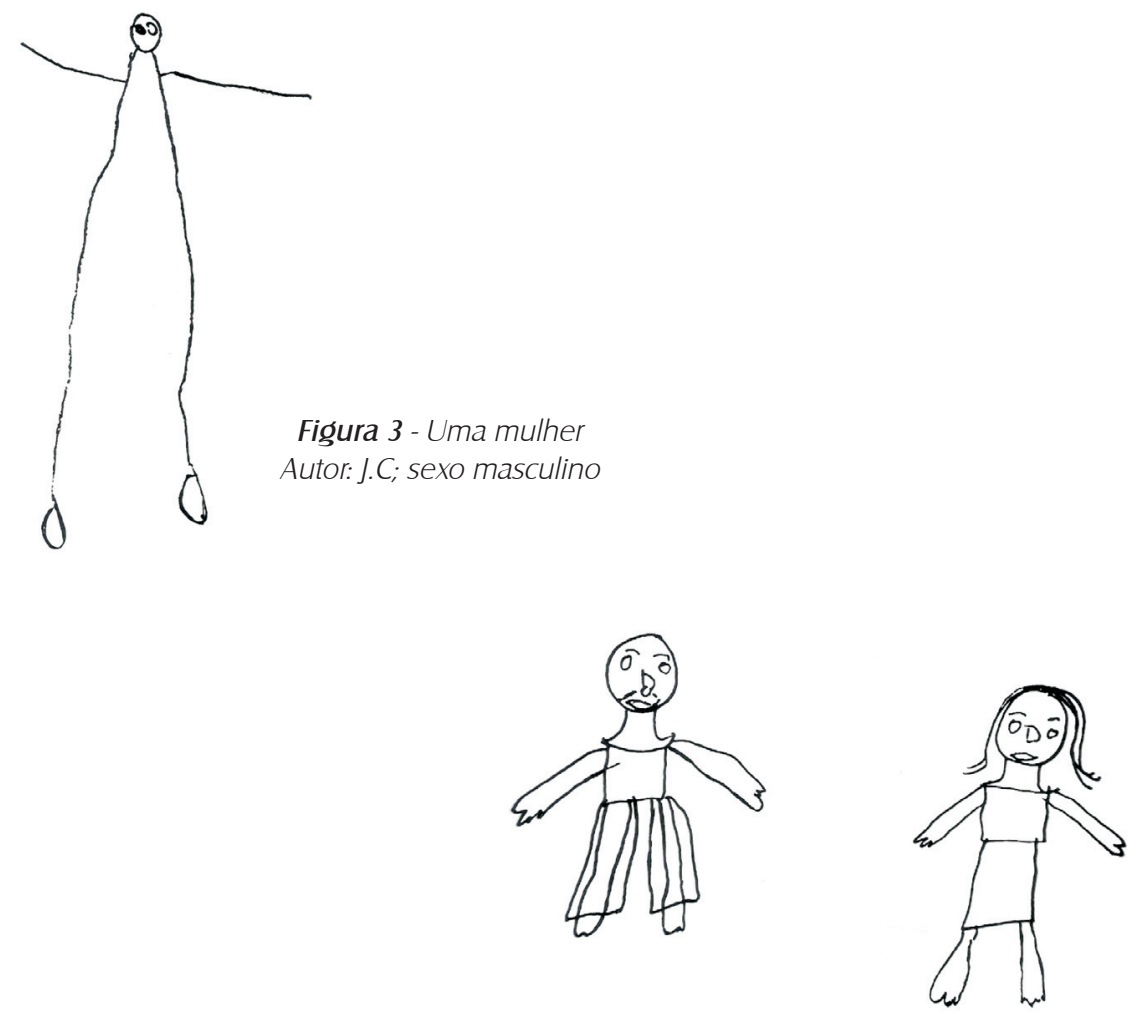

Figura 4 - Os pais

Autor: M.S.B; sexo feminino

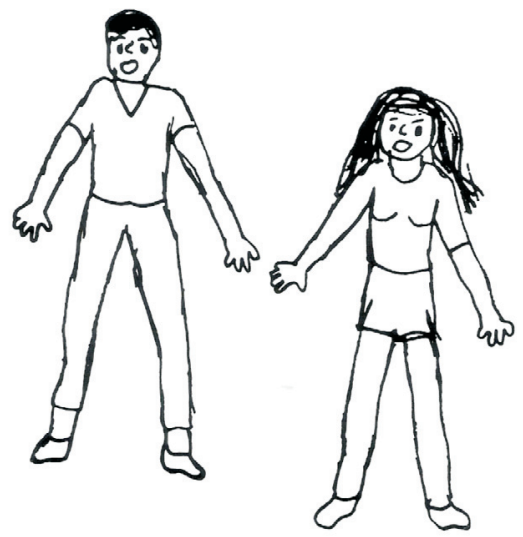

Figura 5 - Os pais

Autor: J. J. H. sexo masculino 
As atividades foram realizadas em ambiente apropriado: amplo, silencioso, com carpete ou esteiras para trabalho com o corpo. Nestas atividades, a delimitação do espaço próprio, não muito afastado dos colegas, contribuiu para o surgimento de clima de confiança mútua entre os alunos e, posteriormente, destes com o (a) condutor (a) do trabalho. Quando namorados participavam da mesma atividade, havia maior espontaneidade e interesse.

A participação dos alunos foi exemplar, principalmente nas atividades relacionadas ao corpo. Para iniciar as discussões, muitas vezes era necessária a intervenção do (a) condutor (a) , seja para colocação lógica dos princípios apresentados ou para levantar questionamentos, devido à vergonha, ao medo, à ignorância ou insegurança diante de alguns temas.

O término das atividades, com dramatização de experiências já vivenciadas (Atividade 12), proporcionou aos alunos a oportunidade de dimensionar os seus conhecimentos, princípios e preconceitos, e trabalha-los no seu meio social habitual - a escola.

Ao final da programação, foi obtida excelente integração da turma e remissão de alguns preconceitos e atitudes sexistas. Foi também solicitado à professora,que acompanhou o grupo, uma avaliação que é apresentada a seguir:

Resolvemos introduzir a Educação Sexual em nossa programação, porque alunos do Pestalozzi com deficiência mental leve ou moderada estavam despertando para o namoro. Para isto, tivemos a colaboração da Dra. Lília e seus estagiários.

A princípio, foi comunicado aos alunos a possibilidade de participarem das oficinas de Educação Sexual, com a devida permissão dos pais, consultados por carta. Como já existiam namorados entre eles, foi uma grande novidade ser

\section{4}


permitido falar de assuntos relacionados à sexualidade e eles acharam muito interessante. Alguns, de início, não se sentiam à vontade para falar sobre sexo e se inibiam muito em responder às perguntas que Ihes eram dirigidas. A dedicação dos orientadores foi muito positiva; com o passar dos dias, os encontros foram mais produtivos, pois os alunos já faziam questão de responder e até de fazerem perguntas. Ficaram sabendo como se comportar, os meios de prevenção da gravidez indesejada, entre outros temas, passando até a dar informaçōes a outros colegas. Sentiram tanta falta daqueles encontros que no final do período letivo passaram a cobrar o retorno dos amigos orientadores.

Profa Célia Santos Carvalho Salvador, dezembro de 1994 


\section{Fundação São Roque - Nazaré \\ Colaboração: Renata Brito ${ }^{1}$}

A sexualidade é um tema muito discutido em escolas, na mídia e em todos os lugares. É um aspecto da individualidade do ser humano que sociabiliza mais do que exclui, visto que é consenso que o prazer é um sentimento bom. Entretanto, às vezes, as diferenças acabam por bloquear a sexualidade como instrumento de socialização impedindo as pessoas de se expressarem em algo tão intrínseco e instintivo que é a sua sexualidade.

A pessoa com deficiência, como outra qualquer, tem a sua sexualidade, que se reprimida, certamente virá a explodir posteriormente, seja na forma de masturbação constante, irritabilidade, timidez, e outros. Fica ainda mais difícil a inclusão de um aluno com deficiência se houverem problemas decorrentes de uma sexualidade reprimida. Por isso é tão importante trabalhar esse aspecto com pessoas excluídas, principalmente com aquelas em que o desenvolvimento de sua sexualidade é mais uma restrição devido a condição que apresentam.

A Atividade Curricular em Comunidade(ACC) é uma proposta educativa, cultural e científica, desenvolvida por professores e estudantes da UFBA, em parceria com grupos comunitários, articuladora de ensino/pesquisa e sociedade. A ACC BIO 456 Genética e Diversidade Humana, em 2006, desenvolveu um projeto interdisciplinar na Fundação São Roque, instituição especializada para pessoas com deficiências no município de Nazaré - Bahia. Neste projeto foram tratados diversos assuntos como higiene, nutrição, inclusão e sexualidade. Na instituição, crianças e adultos es-

${ }^{1}$ Estudante de graduação em Ciências Biológicas e monitora da Atividade Curricular em comunidade (ACC) 2006.2/2007.1

\section{6}


tudam, assistem TV, dormem, alimentam-se e interagem durante o período diurno integral.

O estudo dos prováveis fatores etiológicos associados às deficiências apresentadas pelos alunos permitiu caracterizar 13,5\% de causas genéticas isoladas, 54,5\% da natureza multifatorial ou ambiental e $32 \%$ de causas desconhecidas. Os resultados apontaram para uma maior freqüência de fatores associados ao parto ou à gravidez, assim como para a determinação multifatorial, por interação de condicionantes genéticos e ambientais.

No trabalho de educação sexual, foram feitas oficinas pedagógicas que propiciaram aos alunos, através de atividades lúdicas, aprender mais sobre o assunto e, principalmente, tratar a temática com naturalidade.

Foram selecionadas para o programa as atividades 4 (Um olhar sobre a pessoa com deficiência); 8 (Descobrindo a sua beleza), 11 (Sexo e preconceitos: identificando e discutindo os papéis sexuais) e 13 (Modelo de Oficina utilizando o teatro de bonecos em atividades de educação sexual).

As oficinas de educação sexual eram realizadas em ambiente bem iluminado, com bom espaço. Era colocada uma música suave em baixo volume para deixar o ambiente mais aconchegante.

Para a primeira atividade, foram selecionados alunos com dificuldades maiores de comunicação e relacionamento. No caso de um destes jovens que se mostrava sempre calado, quieto e aparentemente triste, a atividade contribuiu muito para mudança do seu comportamento com colegas e professores. Apenas o fato de ser escolhido para a oficina já aumentou a sua auto-estima e segundo os depoimentos dos professores, tornou-se mais alegre e desinibido, o que facilitou a sua inclusão no grupo.

A atividade sobre os papéis sexuais foi repetida muitas vezes de modo que todos os alunos da escola tivessem oportunidade de participar (Figura 6). O interesse e satisfação foram evidentes. 
Os alunos demonstraram muito interesse no assunto e participaram ativamente dando suas opiniōes e respondendo aos questionamentos, a depender do caso, também com comunicação não-verbal. Muitos dos alunos, escolheram para colar nos seus cartazes, fotos de mulheres de biquíni, dizendo que queriam namora-las (no caso dos meninos) ou ser igual a elas (no caso das meninas), retratando uma posição semelhante à observada na sociedade ocidental em geral, que aceita os rótulos de beleza divulgados pela mídia.

De uma maneira simples e descontraída o assunto foi abordado sem tabus e muitas informaçōes sobre sexualidade e condutas de respeito consigo e com o outro foi passada.

Foi surpreendente a participação e entusiasmo dos participantes nas oficinas de "Teatro de Bonecos" e "Descobrindo a minha beleza". Os resultados mostraram mudanças em termos da auto-valorização e o desejo de estar incluído na comunidade geral da cidade em eventos festivos.

\section{8}




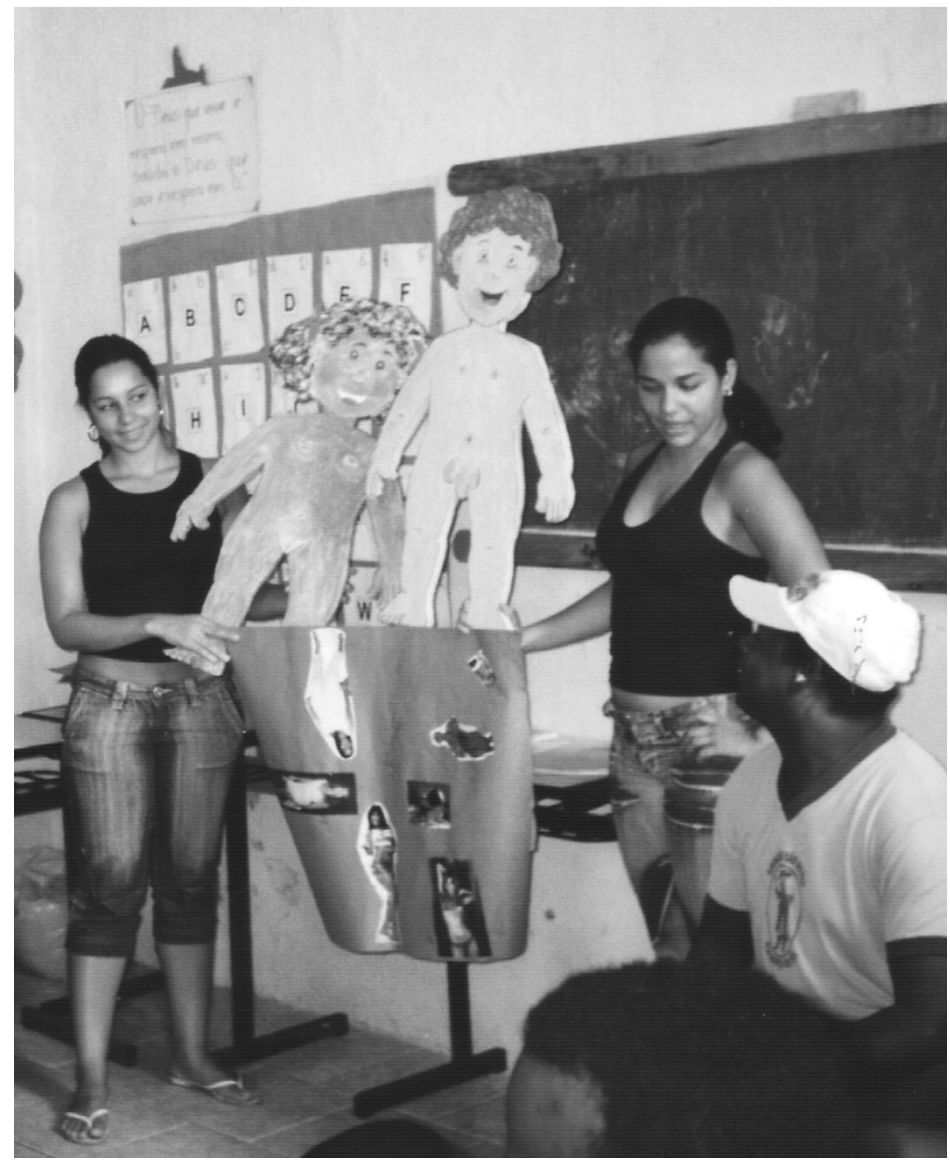

Figura 6 - Discussão sobre gênero e desenvolvimento do corpo. 


\title{
Centro de Reabilitação e Prevenção de Deficiências (CRPD): Obras Sociais de Irmã Dulce
}

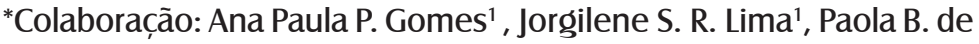
Oliveira', Rodrigo F. de Oliveira'.

As Obras Sociais de Irmã Dulce compreendem uma grande instituição com diversos setores de assistência a população carente. Entre estes setores está o CRPD, que atende não apenas aos que residem na instituição, mas também à comunidade.

O espaço residencial do CRPD funciona no Hospital Santo Antônio, com a supervisão da equipe técnica interdisciplinar e ação direta de funcionários de referência denominados "cuidadores". Estes assumem o papel de chefes de pequenas famílias e participam de toda a experiência educativa.

A partir da demanda dos profissionais da instituição, foram realizadas durante o ano de 1995, oficinas de Educação Sexual com dez moradores, cinco de cada sexo, todos com deficiência intelectual moderada ou severa, com pouca verbalização.

O critério de indicação dos moradores para o trabalho foi a manifestação de curiosidade sexual ou a presença de comportamentos considerados inadequados, a saber: masturbação intensiva, abordagem agressiva ao mesmo sexo ou ao sexo oposto. Constituíram queixas constantes, relatos de:

- masturbação ou auto-manipulação dos órgãos sexuais, muitas vezes em público.

- carícias insistentes em pessoas de sua atração.

\footnotetext{
${ }^{1}$ Estudantes de Psicologia - UFBA.
} 
Tais atitudes podem ser mais acentuadas pela repressão e pouca orientação sexual, pois quanto menos a pessoa com deficiência é orientada, menor é a chance de atuar de modo socialmente adequado.

\section{Participaram das atividades:}

1. A.M., 44 anos, sexo masculino. Síndrome de Down, deficiência intelectual severa. Submissão sexual a companheiro do espaço residencial.

2. S.S., 31 anos, sexo masculino. Macrocefalia, hipodesenvolvimento corporal, paresia de membros inferiores. Solicita dos outros manipulação sexual.

3. A.S., 19 anos, sexo masculino. Paralisia cerebral espástica com comprometimento da área neuro-psicomotora.

4. N.S., 19 anos, sexo masculino. DI associada a distúrbio psíquico. Masturbação muito freqüente.

5. J.P., 16 anos, sexo masculino. Síndrome de Down. DI moderada.

6. M.M., 35 anos, sexo feminino. DI grave, auto-agressividade. Masturbação constante em qualquer lugar.

7. M.D., 32 anos, sexo feminino. Síndrome de Down. DI moderada a severa.

8. D.S., 20 anos, sexo feminino. Hipotireoidismo congênito. DI moderada.

9. A.L., 19 anos, sexo feminino. Síndrome de Down. DI moderada.

10. M.S., 17 anos, sexo feminino. DI pura. Comportamento sexual bastante aflorado.

No início do trabalho, foi realizada a Atividade 2 com as cuidadoras e outros profissionais. Para os moradores da instituição, foram feitas as Atividades 6, 7, 9, 12 a saber: 
- Conhecendo e sentindo o seu corpo

- Sensibilizando o corpo

- Caracterizando as partes do corpo

- Dinâmica de grupo para trabalhar temas diversos relacio nados à sexualidade

O espaço utilizado era uma sala ampla, silenciosa, com pintura clara. O chão era forrado com esteiras ou colchonetes, oferecendo o conforto necessário. As atividades eram realizadas uma vez por semana, em horário previamente estabelecido, aguardado pelos moradores com muita satisfação. Os mesmos compareciam acompanhados de suas cuidadoras, banhados e com boa aparência.

A presença dessas profissionais foi essencial para o êxito do programa. As mesmas prepararam-se para atuar como agentes multiplicadores, além de auxiliar os moradores em tarefas que exigiam maior habilidade motora.

Durante a programação as cuidadoras observaram e discutiram com a equipe técnica a persistência ou modificação dos comportamentos iniciais. Os limites passaram a ser colocados mais claramente e condutas como comportamento agressivo e masturbação em locais coletivos, diminuíram.

A avaliação do programa educativo mostrou que pode haver adaptaçōes para a sua aplicação com pessoas que apresentem deficiência intelectual severa, realizando preferencialmente as atividades referentes ao corpo e substituindo as demais por atividades lúdicas como: banho de mangueira ou piscina, em que pode ser também trabalhado o conhecimento do corpo e cuidados consigo e com o outro e com a organização de festas tradicionais (Carnaval, São João, Primavera, Natal, entre outras) ou

\section{2}


espontâneas, com músicas e danças, e incentivo à alegria e à afetividade (Figura 7). A utilização de jogos e brinquedos no programa de educação sexual, conduzidos de modo positivo e seguro, contribui para a melhora da conduta adaptativa.

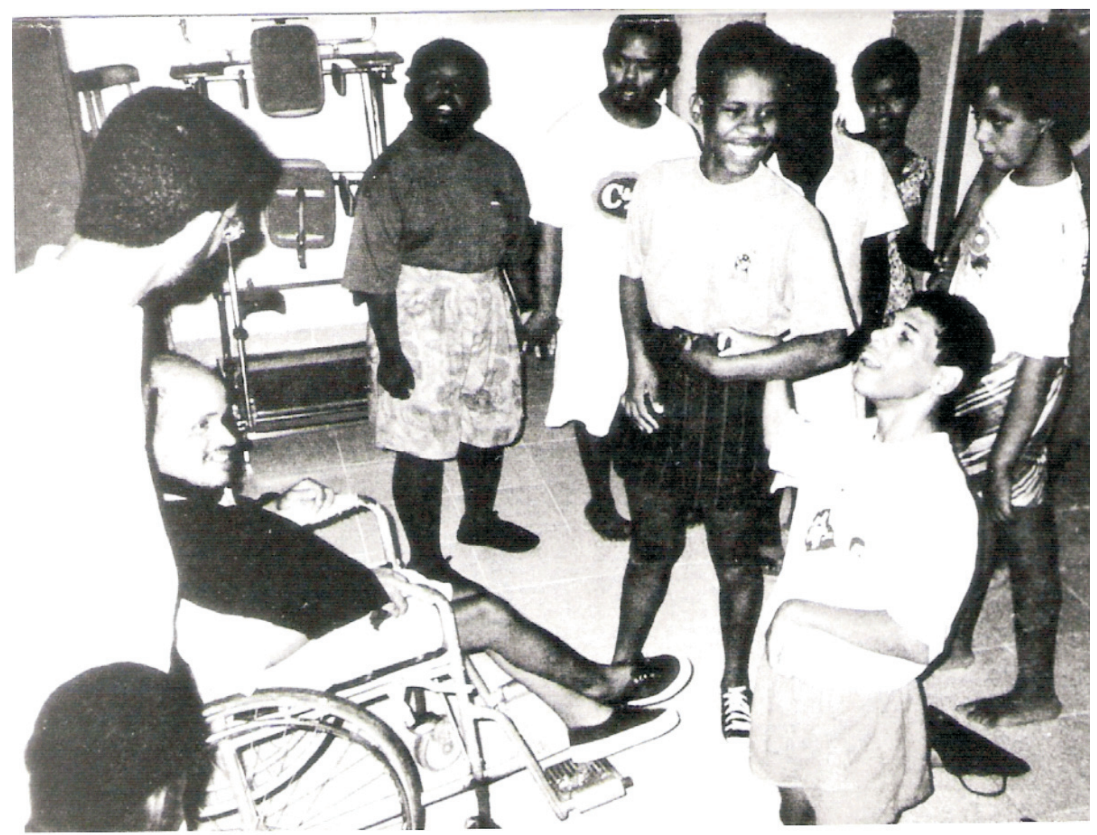

Figura 7 - Oficina espontânea sobre amizade e amor 


\section{O papel dos cuidadores na educação sexual de moradores do Centro de Reabilitação e Prevenção de Deficiências (CRPD): Obras Sociais de Irmã Dulce Colaboração: Yara G. M. de Matos ${ }^{1}$ e Eliane C. Passos²}

O programa de Educação Sexual no CRPD tem se estendido ao apoio da formação técnica dos profissionais denominados cuidadores, com o objetivo de proporcionar reflexões que resultem numa nova postura pessoal frente à questão da sexualidade, ou seja, uma forma mais sensível e mais atenta à educação sexual da pessoa com deficiência intelectual que está sob seus cuidados.

Dentro deste programa, a equipe de mediadores foi convidada a ministrar novas oficinas sobre a temática no segundo semestre do ano de 2005. O primeiro contato com o grupo de profissionais da instituição debateu a questão "Como aconteceu a minha educação sexual?" discutida na atividade 2 do programa. Todos se pronunciaram e foram anotadas as manifestações mais relevantes:

"Não tive em casa e sim na escola com colegas, amigos, na televisão", comentou uma jovem. Uma mãe demonstrou ter dificuldades de conversar com seus filhos de 10 e 12 anos.Um rapaz diz que teve e de forma satisfatória, informações com sua mãe. Uma mulher tornou-se mãe com 16 anos e tem uma filha de 17. Sempre orienta a filha com relação a métodos contraceptivos.

' Especialista em Citogenética Humana pela UCsal. Professora do Colégio Estadual Raphael Serravalle. ${ }^{2}$ Especialista em Citogenética Humana pela UCSal e em Educação Sexual pela Faculdade de Educação da Bahia. Professora do colégio Estadual Henriqueta Catharino.

\section{4}


Fala que se ela engravidar dará todo apoio que também recebeu de seus pais. Uma mãe diz ter dois filhos e que conversam abertamente sobre sexo com ela. Observa entretanto, que a atitude parte sempre dos filhos. Apenas dois participantes tiveram aulas sistematizadas de educação sexual na escola

Após a discussão conduzida pelas mediadoras a respeito do tabu que ainda envolve a educação sexual, foram encerrados os trabalhos com manifestaçōes de emoção e abraços entre os participantes.

No segundo encontro, com o objetivo de sondar as opiniões dos cuidadores sobre as manifestações da sexualidade de pessoas com deficiência intelectual, foi apresentado um questionário com perguntas sobre: comportamento sexual, viabilidade de casamento e reprodução, capacidade dos cuidadores de tratar o tema sexualidade na instituição e, a necessidade de informações e discussōes na temática.

Os questionários foram entregues aos 20 participantes do programa e posteriormente foram devolvidos 13, que, após análise, permitiram as consideraçōes apresentadas a seguir:

Entre os participantes que responderam ao questionário havia uma predominância de mulheres, na faixa etária de 25 a 40 anos. Quando perguntados sobre a sexualidade da pessoa com deficiência intelectual, 69.3\% admitiam ser semelhante a de outras pessoas e 30,7\%, faziam ressalvas quanto à severidade da deficiência. Respostas como "deve ser reprimida" ou "é inexistente" ou ainda, a negação ou repressão da sexualidade não foram cogitadas.

Quando questionados sobre a viabilidade de casamento para pessoas com DI, opinavam que depende de cada caso: 


\begin{abstract}
"Desde que tomem medicação e tenham um bom acompanhamento em todos os sentidos"; "desde que o cognitivo seja compatível com a compreensão das responsabilidades de um casamento"; "desde que não dependam de outras pessoas."
\end{abstract}

Foi também enfatizada a importância do grau de deficiência, a necessidade de autonomia e o apoio familiar e profissional, no manejo do comportamento sexual.

Questionados sobre a viabilidade de terem filhos, 53,8\% achavam inviável, considerando o risco genético. Os 46,2\% restantes observavam que depende de cada caso e destacavam a necessidade de apoio constante nos cuidados com filhos que possam ter.

Quanto à capacidade em lidar com segurança com temas diversos em sexualidade, a maioria $(61,5 \%)$ se considerava preparada; 23\% levava em consideração a pessoa e o caso a ser tratado e apenas 15,5\% não se consideravam capazes, mas não especificavam o motivo.

Quando perguntados sobre as próprias reaçōes diante de manifestaçōes de sexualidade que tenham vivenciado, 30,9\% dos profissionais tiveram a iniciativa de aconselhar a pessoa, 15,3\% repreenderam a manifestação e 7,7\% utilizaram punição para a situação, 46,1\% tiveram outras atitudes como comunicar ao resposável pelo setor ou ficou indiferente.

A maioria dos questionados utilizou revistas e livros na sua capacitação e 30,7\% buscaram capacitação específica. Referiram, também, vontade de receber informaçōes sobre sexualidade e citaram os cursos e as oficinas como os meios mais adequados.

Por sugestão dos próprios cuidadores, foram também tratados temas como fisiologia do aparelho genito-urinário masculi-

\title{
106
}


no e feminino, métodos contraceptivos e masturbação, com apresentação de cartazes como subsídio à discussão. Além disso, com o objetivo de demonstrar as dificuldades para se obter um consenso em temas controvertidos que envolvam valores e sentimentos pessoais e também, demonstrar a diversidade de posturas frente à temas da sexualidade humana, a turma foi dividida em quatro grupos e ao som da música Jardins da Babilônia (Rita Lee e Roberto Carvalho), foram analisadas situaçōes-problemas no contexto da moradia, algumas das quais adaptadas de CoeIho, 1987.

\section{Situação/Problema 1}

"Tenho 22 anos, nunca namorei e ainda sou virgem. Eu quero saber se eu sendo Down, posso namorar e casar?"

A maioria concordou com a possibilidade de namorar e casar, mas foram unânimes na necessidade de um acompanhamento familiar e profissional. Todos também, salientaram depender do grau de deficiência intelectual considerando que para o DI mais severo as dificuldades seriam maiores.

\section{Situação/Problema 2}

"Durante as atividades de aula em uma classe, um dos rapazes de 15 anos, portador de deficiência intelectual, baixou as calças e começou a se masturbar. Qual seria a sua atitude diante desse fato?"

Todos consideraram a masturbação um comportamento normal mas inadequado nesta situação. A maioria opinou ser necessário uma intervenção imediata e de forma 
cuidadosa orientar o jovem, esclarecendo que o procedimento não foi apropriado no local e no momento considerado.

\section{Situação/Problema 3}

"Partindo do princípio de que pessoas com deficiência intelectual têm direito a uma vida sexual ativa, como pode ser encarado o problema do controle da natalidade?"

Quanto a esta questão todos concordavam que o controle da natalidade deve ser praticado com essas pessoas. Alguns sugeriram orientação e prevenção com pílula anticoncepcional e uso da "camisinha", outros foram mais radicais sugerindo ligadura de trompas e vasectomia.

\section{Situação/Problema 4}

"Uma moça opta por fazer tabelinha ao invés de usar pílula contraceptiva (que Ihe causa alguns efeitos colaterais), porque mantém relações eventuais com o namorado. Qual a sua opinião a esse respeito?"

Nessa questão, todos foram unânimes quanto ao risco do uso do método em questão. A sugestão geral foi a combinação da "tabelinha" com o uso do preservativo, principalmente para evitar as doenças sexualmente transmissíveis.

Mais uma atividade e dessa vez para avaliação e encerramento dos trabalhos. Foi concluído que a educação sexual deve constituir tema de educação continuada.

Nos encontros realizados, os cuidadores tiveram a

\section{8}


oportunidade de refletir sobre sua educação sexual e adquirir subsídios para uma mudança e crescimento da postura pessoal diante das questões da sexualidade e especialmente em relação à pessoa com deficiência intelectual que está sob os seus cuidados. Puderam perceber que são fundamentais o respeito e a aceitação desta pessoa e da sua sexualidade, embora reconhecidamente seja uma tarefa muito difícil. A sexualidade do indivíduo com deficiência intelectual não é, intrinsecamente, diferente ou problemática; não existe distúrbio da sexualidade do deficiente intelectual, mas dificuldades na manifestação da sexualidade.

A capacitação de cuidadores, pais e profissionais contribui de modo importante na orientação do desenvolvimento psicossexual da pessoa com deficiência intelectual, o que certamente beneficiará a inclusão social dessas pessoas. 

"É através de uma interação constante entre o biológico e o cultural. durante o desenvolvimento da criança, que podem amadurecer e organizar-se as estruturas nervosas que servem de suporte às realizações mentais"

François Jacob. 1989 



\section{Desenvolvimento e crescimento humano: da concepção à puberdade}

O desenvolvimento de um organismo inclui todas as mudanças morfológicas e fisiológicas que contribuem para o curso de seu ciclo de vida. Em formas unicelulares, as mudanças são restritas e ocorrem dentro da própria célula. Entretanto, para formas multicelulares, as mudanças incluem todas as atividades que ocorrem nas células, tecidos, órgãos e sistemas de diferenciação e integração.

A diferenciação celular que causa o desenvolvimento morfológico e a especialização funcional é acompanhada por uma contínua síntese e degradação de enzimas e outras proteínas que estão sobre controle genético.

Os fatores genéticos contidos no ovo ou zigoto apresentam capacidades morfofisiogênicas potenciais. Os genes estão presentes principalmente nos cromossomos do núcleo celular, sendo metade oriundos da mãe e metade paternos. O conjunto desses atributos individuais constitui o genótipo.

A partir de um único ovócito fertilizado, desenvolvem-se diferentes tipos de células. Os mecanismos pelos quais é regulada a expressão diferencial do material genético não são ainda bem conhecidos. No controle do desenvolvimento atuam os chamados genes homeobox, grupos de genes interrelacionados deno- 
minados Hom em invertebrados e Hox em vertebrados, que determinam aspectos semelhantes no desenvolvimento do corpo. Um dos aspectos principais na genética do desenvolvimento refere-se ao modo pelo qual ocorre a ativação seqüencial dos genes no início deste processo.

A expressão e manifestações decorrentes do genótipo podem ser modificadas pela ação ambiental. Por exemplo, na fenilcetonúria, que é uma condição gênica (doença autossômica recessiva), o uso da dieta sem fenilalanina (presente na maioria dos alimentos) impede o aparecimento das manifestaçōes clínicas da doença. Um exemplo onde condições ambientais não interferem na expressão de genes mutados é a microcefalia autossômica recessiva. No caso do genótipo não ter sofrido nenhuma alteração, condições ambientais do tipo infecção intraútero, drogas, radiaçōes, podem levar a fenocópias, condiçōes patológicas semelhantes àquelas produzidas por mutações gênicas, como no caso da toxoplasmose congênita, causando a microcefalia. Outras manifestaçōes no indivíduo dependem da capacidade de expressão do seu genótipo.

É muito importante considerar que a influência dos genes não se manifesta somente no momento da concepção, no período embrionário, no nascimento ou ainda em momentos determinados da história de vida dos indivíduos. Os processos de desenvolvimento estão sujeitos a contínuas influências genéticas e genes diferentes podem manifestar a sua ação em épocas distantes. Assim, a distrofia muscular do tipo Duchenne, de herança recessiva e ligada ao sexo, se manifesta a partir do primeiro ano de vida, de modo progressivo, sem que fatores ambientais possam influenciar neste processo que leva à morte do indivíduo, muitas vezes até a segunda década de vida.

Em relação ao crescimento, poucas funções biológicas dependem tanto do potencial genético quanto esta. Entretanto, desde o momento da concepção, o ambiente pode perturbar a

\section{4}


ordenação, qualidade e quantidade do fenômeno: o crescimento depende, na verdade, da integração organismo/ambiente.

Crescimento e desenvolvimento são processos paralelos, mas com conceitos próprios e não obrigatoriamente dotados de igual velocidade ou de igual sensibilidade aos agravos. Crescimento é aumento de massa por hipertrofia e divisōes celulares (passível de aferição por meio de cm e kg) e desenvolvimento é a aquisição de capacidade (somente passível de aferição por meio de provas funcionais).

O crescimento humano se caracteriza por 4 fases nitidamente distintas:

\section{Fase 1}

Crescimento intra-uterino, inicia-se na concepção e vai até o nascimento.

\section{Fase 2}

Primeira infância, vai do nascimento aos dois anos de idade, aproximadamente, caracterizando-se por um crescimento incremental, que se inicia no nascimento e estende-se até um mínimo marco inicial da fase seguinte.

\section{Fase 3}

Segunda infância ou intermediária, período de equilíbrio e crescimento uniforme em que o acréscimo anual de peso se mantém no mesmo nível, desde o mínimo limítrofe, anteriormente citado, até o início de uma nova fase de crescimento acelerado.

\section{Fase 4}

Adolescência, fase final de crescimento, que se estende mais ou menos dos dez aos vinte anos de idade. O 
crescimento inicialmente se acelera, até atingir um máximo em torno dos quinze anos e, depois, declina rapidamente até os 20 anos.

O crescimento, analisado globalmente, é a somatória de fenômenos celulares, bioquímicos, biofísicos e morfogenéticos, cuja integração é feita segundo um plano pré-determinado pela herança, modificado pelo ambiente (MARCONDES,1970).

Em condições normais, cada célula, cada tecido e cada órgão crescem em graus, padrões e velocidades próprias. Há 4 tipos fundamentais de crescimento das estruturas do corpo:

\section{Crescimento geral somático}

Corpo como um todo, dimensões externas (com exceção da cabeça e pescoço), tecido muscular e ósseo, volume sangüíneo, órgãos dos aparelhos respiratório, circulatório e digestivo, rim e baço. Este tipo de crescimento pode ser representado pela curva de peso e estatura, que apresentam aspecto geral de um S, com dois períodos de maior velocidade (zero a dois anos e por ocasião da puberdade).

\section{Crescimento neural}

Cérebro, cerebelo e estruturas afins, aparelho ocular, perímetro cefálico. Este tipo caracteriza-se por uma intensa velocidade nos dois primeiros anos de vida.

\section{Crescimento linfóide}

Timo, gânglios linfáticos, amídalas, adenóides, folículos linfóides intestinais. O desenvolvimento máximo das estruturas linfóides ocorre entre os oito e dez anos de idade. 


\section{Crescimento genital}

Testículos, ovários, epidídimo, vesículas seminais, próstata, útero e anexos. Estas estruturas permanecem quiescentes durante os primeiros oito a dez anos de vida, para então apresentar um crescimento acelerado, dentro das transformaçōes físicas que correspondem à puberdade.

As Figuras 8 e 9 apresentam, transformações no corpo do homem e da mulher, decorrentes do processo de crescimento e desenvolvimento. Veja nas páginas seguintes:

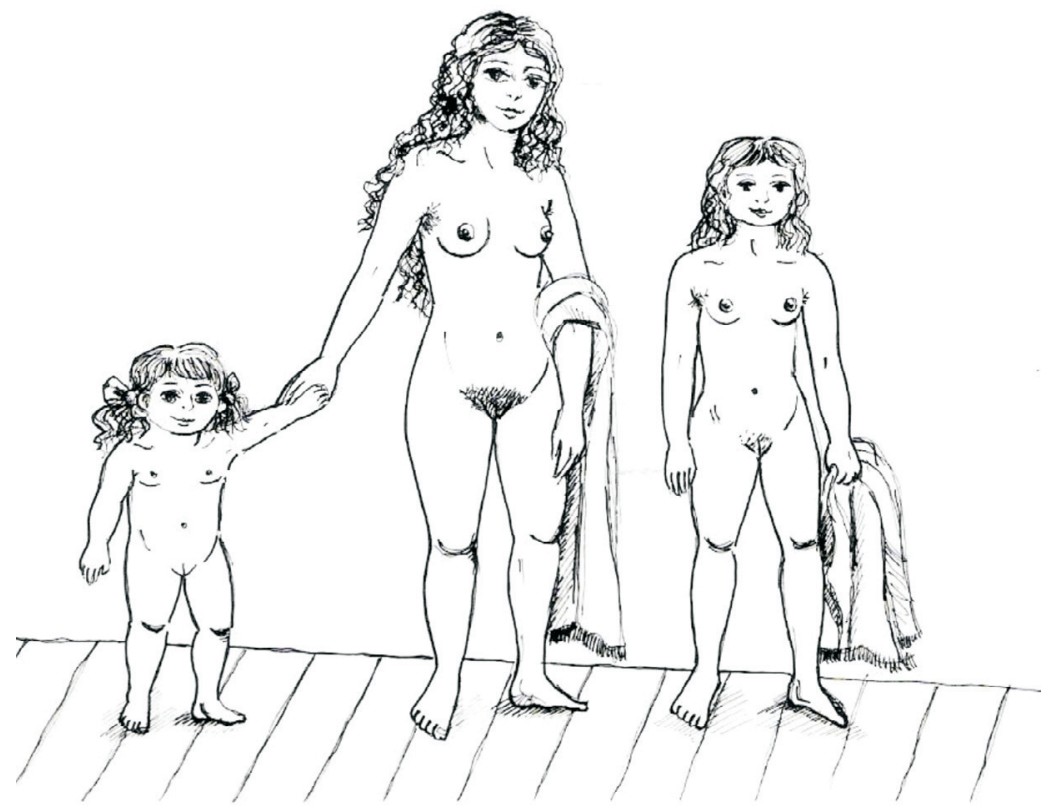

Figura 8 - Transformações no desenvolvimento feminino. De menina para mulher (09 a 16 anos) Sinais principais: Aumento de estatura e peso; presença de pêlos pubianos e axilares; desenvolvimento dos seios; amadurecimento do aparelho reprodutor. 


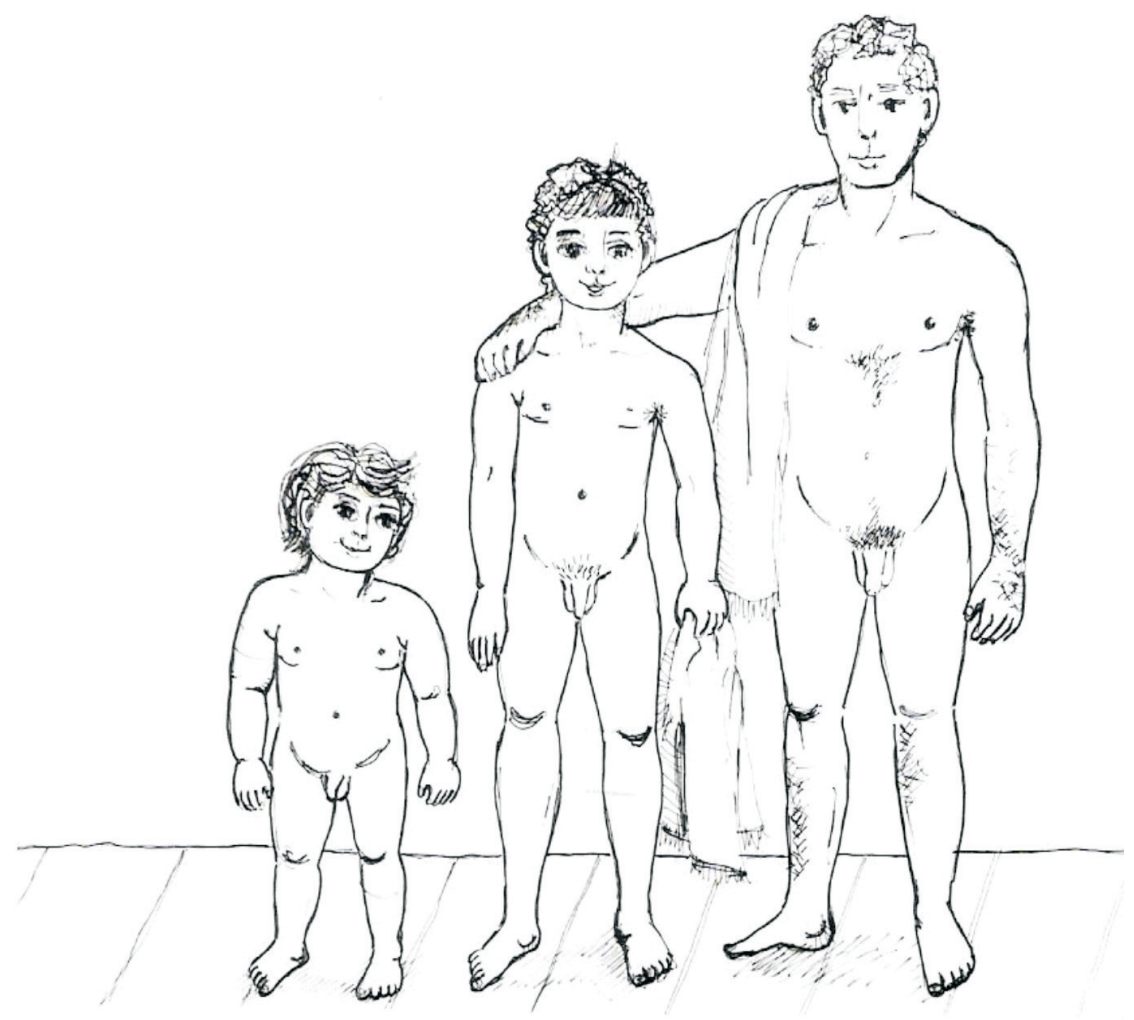

Figura 9 - Transformação no desenvolvimento masculino. De menino para homem (11 a 18 anos). Sinais principais: aumento de estatura e peso; desenvolvimento muscular; presença de pêlos pubianos e axilares; amadurecimento do aparelho reprodutor; modificação da voz; surgimento da barba. 
O desenvolvimento da sexualidade segue um programa biológico básico que se inicia na lactância, quando bebês de ambos os sexos apresentam estimulação oral ou manual. A sexualidade humana pode ser caracterizada de acordo com as diferentes etapas do desenvolvimento em:

\section{Fase da Primeira Infância}

Do nascimento até os 4 anos de idade.

\section{Fase Pré-escolar (período edipiano)}

Abrange dos 4 aos 6 anos de idade.

Fase da Segunda Infância (período de latência)

Dos 6 anos até a puberdade.

Fase da Adolescência (da puberdade até a idade adulta) Dos 10 até os 18 anos. Nesta fase os caracteres sexuais secundários desenvolvem-se evidenciando o dimorfismo entre os gêneros. É a etapa principal de formação dos casais.

Fase da Maturidade

Compreende a idade adulta.

Fase da Velhice ou Idade Avançada (da menopausa até o fim da vida)

Menopausa Feminina (entre 45 e 55 anos)

Menopausa Masculina (por volta dos 50 anos de idade) 
De acordo com a teoria freudiana, a evolução psicossocial da criança ocorre de forma gradual. O prazer experimentado pela obtenção de sensaçōes agradáveis concentra-se em três zonas características, determinando diferentes estágios, que acompanham a sua maturação e desenvolvimento e se constituem a base do relacionamento entre a criança, a mãe e o meio que a circunda (ASSUMPÇÃO; SPROVIERI, 1987):

\section{Estágio Oral}

Corresponde aos dois primeiros anos de vida e tem como característica básica à relação da criança com o mundo externo através da boca. A criança experimenta por essa regiāo, além do prazer alimentar, o contato físico e afetivo com a mãe.

\section{Estágio Anal}

Ocorre entre os dois e quatro anos, quando a criança começa a controlar os esfíncteres. Experimenta atividade auto-erótica pela retenção e expulsão das fezes, estabelecendo-se também uma relação com o meio.

\section{Estágio Fálico}

Quando a criança está entre os quatro e seis anos de idade. Nesta fase, o prazer é centrado no pênis, nos meninos, e no clitóris, nas meninas. Ocorre a relação com uma terceira pessoa, caracterizada pela figura do pai, e o estabelecimento de uma relação edipiana acompanhada de sentimentos diversos de admiração, afeto e hostilidade, que levam à formação do superego, pelo conflito das emoçōes e interdições decorrentes. 


\section{Estágio de Latência}

Fase de desenvolvimento que se estende dos seis anos até o início da adolescência, por volta dos onze anos. Ocorre uma aparente diminuição do interesse sexual.

\section{Adolescência}

Período compreendido entre a puberdade e a vida adulta, por volta dos dezoito aos vinte anos. Sob a influência hormonal, os órgãos genitais maturam, o prazer e o desejo sexual manifestam-se.

A adolescência é um período de crise: além das modificaçōes físicas, ocorrem também as comportamentais. Surgem os relacionamentos afetivos, o "ficar" e o "namorar", que podem significar para o adolescente um caminho seguro para o desenvolvimento afetivo e aquisição de autonomia psíquica. Da infância à adolescência, o indivíduo amplia as suas habilidades através de progressos físicos e mentais que levam à maturidade.

Dentro das etapas do desenvolvimento de Piaget, enquanto que a fase sensório-motora (zero a dois anos) é caracterizada pela exploração corporal, na fase pré-operatória (dois a seis anos) é iniciado o reconhecimento das diferenças morfológicas e fisiológicas entre os meninos e meninas (Figura. 9), importantes na estruturação cognitiva dos modelos masculino e feminino. A identidade sexual é estabelecida em torno dos cinco a seis anos e ocorre quando as diferenças são interiorizadas, levando a organização dos papéis sexuais. 
O papel sexual é tudo o que alguém diz e faz que indique a si próprio e aos outros - que é homem ou mulher, constituindo a expressão pública da sua identidade sexual (TUCKER; MONEY, 1981). No que se refere à pessoa com deficiência mental, o processo de identidade e tipificação sexual apresenta-se lentificado em razão da maior dificuldade de estruturação dos conceitos de Eu e do Mundo (ASSUMPÇÃO Jr.; SPROVIERI, 1987).

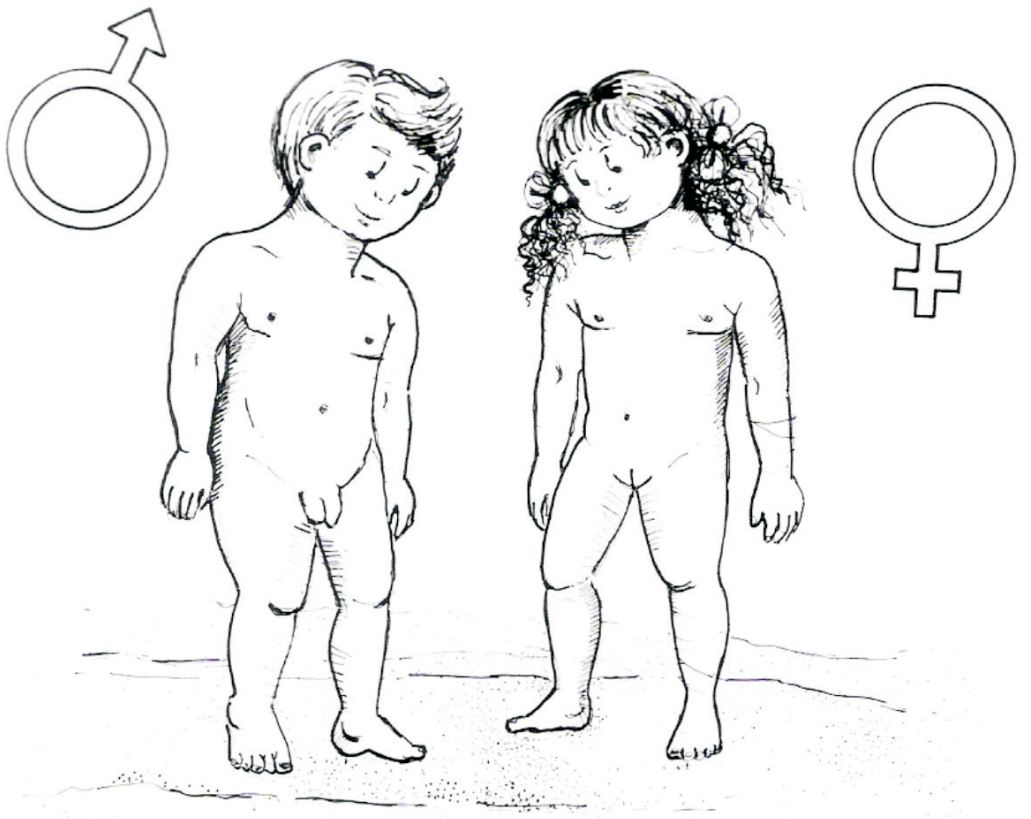

Figura 10 - Diferenças sexuais 
"Vou-me embora pra Pasárgada Lá sou amigo do rei Lá tenho a mulher que eu quero na cama que eu escollherei (...) Em Pasárgada tem tudo É outra civilização Tem um processo seguro De impedir a concepção" Manuel Bandeira. 1986 



\section{Métodos contraceptivos e suas características}

A orientação em planejamento familiar é uma prática de essencial importância para qualquer pessoa, proporcionando informações corretas que levem em conta o seu papel sexual, sua história de vida, crenças e valores. A tomada de consciência da responsabilidade da procriação é fundamental para que o indivíduo, independente do fato de apresentar ou não alguma deficiência, venha a ter uma vida sexual saudável.

No caso específico das pessoas com deficiência intelectual, é extensa a discussão ética sobre o direito ou não destes terem filhos. Glat e Freitas (1996) observam que a esterilização em homens ou mulheres relativamente jovens, ainda que tenham deficiência, deve ser analisada com muito cuidado.

Deve ser levado em conta que há diversos níveis de deficiência mental e em muitos casos o déficit intelectual não impede a conversa sobre o assunto, às vezes com o auxílio do médico ou do terapeuta.

O desconhecimento dos métodos contraceptivos pode conduzir a uma gravidez não-planejada, muitas vezes resolvida com a solução não-desejada do aborto ou levando a problemas na aceitação da criança nascida nestas circunstâncias. 
A prevenção da gravidez indesejada realiza-se pela aplicação dos métodos de controle de natalidade, reversíveis ou irreversíveis, mostrados a seguir. É também apresentado o índice de falha dos métodos, de acordo com Bello e col. (1985) e Cavalcanti (1992).

\section{MÉTODOS REVERSíVEIS (NÃO-DEFINITIVOS)}

\section{Tabelinha}

* Método natural que consiste em evitar relações sexuais durante o período fértil, isto é, o período do mês em que ocorre a ovulação. Para evitar gravidez, o período pode ser calculado com o uso da tabelinha, considerando que o ciclo menstrual começa no primeiro dia da menstruação e termina no último dia antes da próxima menstruação. No caso de ciclo de 28 dias, contando-se 10 dias a partir do início da menstruação (por exemplo, dia 2), e 10 dias para trás do dia da próxima menstruação (dia 29), é delimitado o período fértil.

* MODO DE USAR: não ter relações sexuais com penetração vaginal no período fértil.

* ÍNDICE DE FALHA: entre 14 - 47\%

* OBSERVAÇÃO: para utilizar este método, a mulher deve determinar a duração do seu ciclo menstrual, marcando os dias do início da menstruação por cerca de 12 meses. O método apresenta menos erros em mulheres com ciclos regulares. Para quem não deseja engravidar, os dia mais seguros são: 
- Os dias da menstruação.

- 3 dias depois da menstruação.

- 7 dias antes da próxima menstruação.

\begin{tabular}{ccccccc}
\multicolumn{7}{c}{ MARÇO } \\
D & $S$ & $T$ & $Q$ & $Q$ & $S$ & $S$ \\
& & 1 & 2 & 3 & 4 & 5 \\
6 & 7 & 8 & 9 & 10 & 11 & 12 \\
13 & 14 & 15 & $(16$ & 17 & 18 & 19 \\
20 & 21 & 22 & 23 & 24 & 25 & 26 \\
27 & 28 & 29 & 30 & 31 & &
\end{tabular}

\section{Método da ovulação ou do muco cervical (método billings)}

* Observar a variação do muco vaginal conforme o período fértil.Cerca de 2 a 3 dias após a menstruação, não se verifica a presença de muco. Com o início do período fértil, o muco aparece. Na ovulação, o muco torna-se ralo, semelhante à clara de ovo. Depois da ovulação, o muco deixa de ser verificado.

* MODO DE USAR: não ter relações sexuais nos dias com muco (molhados).

* ÍNDICE DE FALHA: 2 a 25\%

* OBSERVAÇÃO: este método não pode ser usado quando a mulher está com corrimento ou infecção vaģinal. 


\section{Temperatura (Método de Ogino-Knauss)}

* A temperatura normal do corpo varia de 36 a $36,5^{\circ} \mathrm{C}$. Pela medida diária da temperatura da mulher, antes de levantar, verifica-se que diminui um pouco, um dia antes da ovulação, para depois subir, no dia da ovulação.

* MODO DE USAR: medir a temperatura e evitar ter relação com penetração quatro dias antes e quatro dias após o dia em que a temperatura sobe.

* ÍNDICE DE FALHA: variável. Como o anterior, depende da motivação do casal, além do fato que a temperatura do corpo pode variar por outros fatores.

* OBSERVAÇÃO: o método pode ser utilizado em conjunto com a tabela e o muco (métodos denominados naturais), aumentando a sua eficiência.

\section{Coito interrompido}

* Praticado quando o homem retira o pênis da vagina antes da ejaculação.

* ÍNDICE DE FALHA: 3 a 12\%

* OBSERVAÇÃO: método pouco seguro, que depende do controle masculino. Alguns espermatozóides podem escapar antes da ejaculação, diminuindo assim a eficiência do método.

\section{Camisinha, condom ou preservativo}

* Capa de borracha fina usada pelo homem, que impede o sêmen de entrar no útero feminino.

* MODO DE USAR: colocar antes da penetração, com o pênis em ereção, deixando uma folga na ponta e 
apertando-a para tirar o ar. Desenrolar a camisinha até a base do pênis (Figura 11). Depois da ejaculação, retirar o pênis ainda ereto, segurando o preservativo pela borda, para evitar vazamento do sêmen. Após este procedimento, descartar a camisinha, que é utilizada apenas uma vez.

* ÍNDICE DE FALHA: 3 a 12\%

* OBSERVAÇÃO: além de método anticoncepcional bastante seguro (se utilizado corretamente), apresenta barreira contra doenças sexualmente transmissíveis.
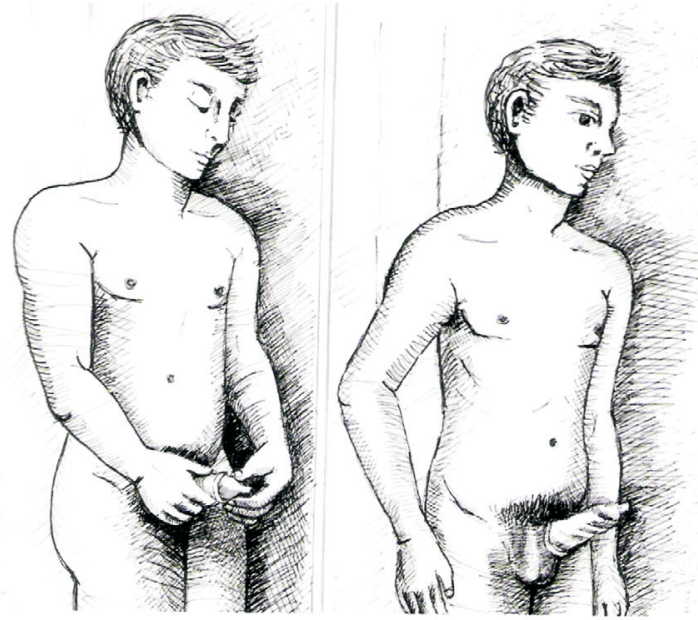

Figura 11 - Modo de utilizar corretamente a camisinha deixando folga na ponta e colocando-a no pênis ereto

\section{Preservativo ou camisinha feminina}

* Bolsa, com forma de tubo, fina e resistente, que é colocada dentro da vagina, com finalidade contraceptiva.

* OBSERVAÇÃO: é menos popular que o preservativo masculino convencional, mas fornece proteção adicional contra a infecção pelo papiloma vírus humano (HPV) e o herpes, ao recobrir a regiaão dos lábios vaginais. 


\section{Espermicidas}

* Geléias, cremes, comprimidos ou óvulos que, quando aplicados na vagina, destroem os espermatozóides e evitam a gravidez.

* MODO DE USAR: deve ser colocado profundamente na vagina, cerca de 10 a 15 minutos antes da relação sexual. * ÍNDICE DE FALHA: 8 a 42\%. São mais eficazes quando utilizados junto com camisinha ou diafragma.

* OBSERVAÇÃO: algumas mulheres podem apresentar irritação ou alergia na vagina, devendo, neste caso, mudar a marca ou deixar de usar o método.

\section{Diafragma}

* Pequeno disco de borracha que se coloca dentro da vagina, e funciona como barreira, impedindo a entrada dos espermatozóides.

* MODO DE USAR: colocar o diafragma com o dedo. Para retirar, esperar 8 horas, que é o tempo que os espermatozóides podem sobreviver dentro da vagina.

* ÍNDICE DE FALHA: 3 a 18\%

* OBSERVAÇÃO: exige consulta médica para orientação quanto ao uso e conservação e também cuidados na sua utilização. Sendo lavado e conservado seco, pode durar até 2 anos.

\section{Diu (dispositivo intra-utrino)}

* Aparelho que, colocado dentro do útero, impede a ocorrência da gravidez. É um pequeno objeto de plástico sobre o qual, muitas vezes, é enrolado um fio de cobre muito fino, e que se apresenta em diversos formatos (Figura 12). 
* MODO DE USAR: a colocação, que é simples e rápida, deve ser feita apenas pelo médico. É colocado no útero, geralmente durante o período menstrual, a fim de eliminar qualquer risco de gravidez. A sua ação consiste em provocar uma reação a nível da mucosa uterina, o endométrio, impedindo a implantação do óvulo fecundado.

* ÍNDICE DE FALHA: depende do tipo - Tcu 200, de 1 a 5\%, e Tcu 380a, de 0,3 a 1\%.

* OBSERVAÇÃO: É um método reversível bastante eficaz, entretanto, algumas mulheres não se adaptam ao DIU. Os efeitos colaterais mais freqüentes são cólicas e menstruações muito abundantes e prolongadas.

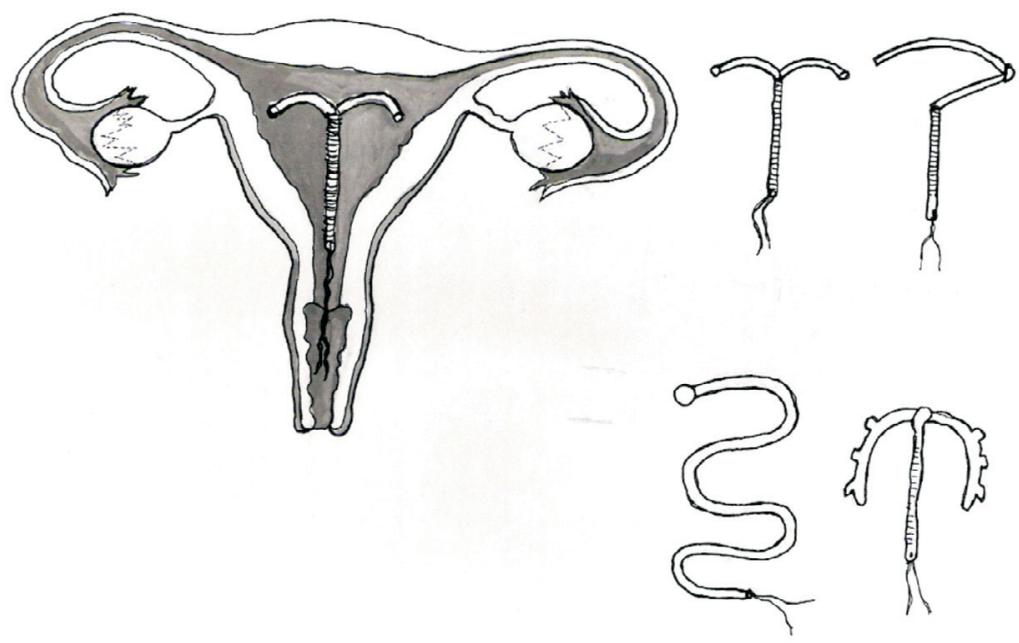

Figura 12 - Diferentes tipos do Dispositivo Intra-uterino (DIU). 


\section{Pílula anticoncepcional}

* Comprimido composto de hormônios em várias misturas de estrógenos e progesterona, que impossibilita a liberação do óvulo pelo ovário, e assim, impede a fecundação. A minipílula apresenta só um tipo de hormônio progesterona, em doses baixas.

* MODO DE USAR: o tipo mais comum é o da cartela com 21 comprimidos, que se começa a ingerir 5 dias depois do início da menstruação.

* ÍNDICE DE FALHA: 0,1 a 3\%

* OBSERVAÇÃO: é o método anticoncepcional mais seguro. Apresenta contra-indicaçōes para mulheres que:

- estão grávidas ou amamentando.

- apresentam perdas sangüíneas vaginais fora do período menstrual

- apresenta enxaquecas.

- têm resultado anormal no exame preventivo de câncer (Teste de Papanicolau).

- têm ou tiveram estas doenças como: hepatite, mononucleose, tumor do fígado ou cirrose, câncer no seio, ovário ou útero, trombose, flebite, derrame, embolia, enfarto, angina no peito, diabetes.

\section{Anticoncepcionais injetáveis}

* Consiste no uso mensal ou trimestral de hormônio em forma de injeção. Coutinho (1996), considera este anticoncepcional, comercializado com o nome de Depo Provera e Farlutal 500 AD, como ideal para suprimir a menstruação.

Os progestógenos injetáveis, além de anovulatórios, aumentam a viscosidade do muco cervical, tornam o 
endométrio menos propício à implantação do ovo e alteram a motilidade tubária.

* MODO DE USAR: anticoncepcional injetável mensal é aplicado via intramuscular profunda, uma vez ao mês, entre o $7^{\circ}$ e o $10^{\circ}$ dia do ciclo menstrual. A Depo Provera é usada mais comumente na dose de $150 \mathrm{mg}$ a cada 90 dias (SPINOLA, 1995).

* ÍNDICE DE FALHA: 0,3 a 0,4\%

* OBSERVACCÃO: o método requer supervisão mínima e tem efeito prolongado, sendo recomendável para pessoas com deficiência mental. Entretanto, para a sua escolha, deve ser avaliada a ausência de contra-indicaçōes, como câncer, cardiopatias, doenças do fígado. Devem ser também levadas em conta as desvantagens do método, principalmente a irregularidade menstrual, aumento de peso e certa demora para retornar a fertilidade.

\section{Implantes sudérmicos: Norplant}

* Implantes subcutâneos de tubinhos ou cápsulas de plástico especial (silástico), contendo hormônio anticoncepcional. O implante, feito na parte interna do braço ou antebraço, vai liberando o hormônio lentamente.

* MODO DE USAR: a colocação é feita durante a menstruação, com agulha especial e anestesia local. O Norplant dura cinco anos.

* ÍNDICE DE FALHA: 1\%

* OBSERVAÇÃO: método de larga duração e de alta eficácia. Entre os efeitos colaterais, pode ocorrer irregularidade menstrual.

Centros de investigação sobre a biologia da reprodução humana continuam a desenvolver pesquisas no sentido 
de aperfeiçoar os métodos contraceptivos, tornando-os mais seguros e baratos. Está em estudo o uso do Gossypol como anticoncepcional masculino (COUTINHO e ATHAYDE, 1995). O Gossypol é um pigmento amarelo extraído da semente de algodão que inibe a espermatogênese do homem e em várias espécies animais. As primeiras observações clínicas na China revelam que o Gossypol não produz aumento do peso, não interfere na potência sexual nem na libido. Entretanto, 10\% dos usuários mostram ação hipokalemiante, provocando fraqueza e cansaço.

\section{Anticoncepcional de emergência - pílula do dia seguinte}

* Esse método deve ser usado em uma situação inesperada. É indicado para a mulher que manteve uma relação sexual não planejada, sem uso de anticoncepcional e em casos de estupro. É também indicado em situaçōes de rompimento de camisinha ou quando o diafragma é removido antes de seis horas após uma relação sexual, ou após esquecimento de uma ou mais pílulas anticoncepcionais no início ou no fim da cartela. Consiste no uso de altas doses de pílulas anticoncepcionais orais (contendo estrogênio + progestogênio) que interrompem o ciclo reprodutivo da mulher, evitando assim uma gravidez indesejada. Dependendo da etapa do ciclo na qual as pílulas foram tomadas, elas podem impedir ou retardar a liberação do óvulo pelo ovário. Algumas usuárias têm efeitos colaterais, tais como náuseas e vômitos ou distúrbios do ciclo menstrual. Efeitos colaterais sérios são muito raros. Pode ser usada por mulheres de qualquer idade, com ou sem filhos.

\section{4}


* MODO DE USAR: Uso em até 72 horas após a relação sexual.

* ÍNDICE DE FALHA: Baixo, quando ingerida no período indicado.

\section{MÉTODOS IRREVERSÍVEIS (DEFINITIVOS)}

\section{Ligação de trompas (laqueadura)}

* É um método cirurgíco em que as trompas de Falópio são amarradas e seccionadas, impedindo que os óvulos alcancem o útero e sejam fecundados pelos espermatozóides (Figura 13). Outra técnica em desenvolvimento consiste na oclusão tubária pela colocação do agrafo ou anel (técnica do ring) em cada trompa, oferecendo a chance de reversibilidade em 30\% dos casos.

* OBSERVAÇÃO: exige cirurgiia; impróprio para mulheres que podem querer ter filhos no futuro.

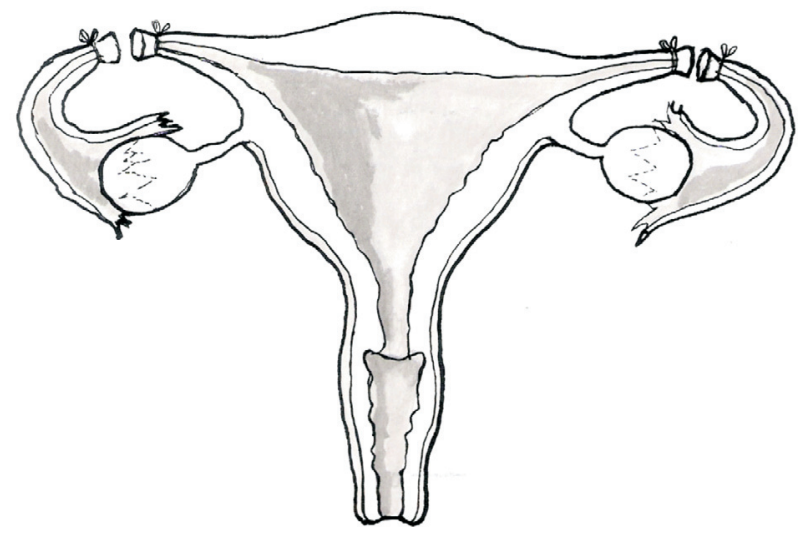

Figura 13 - Laqueadura de trompas 


\section{Vasectomia}

* É um método contraceptivo masculino que consiste em uma operação que secciona o canal deferente (tubo que conduz o esperma para a uretra), Figura 14.

O homem submetido a esta operação tem prazer sexual normal e orgasmo, mas seu sêmen não contém espermatozóides, e assim não pode fecundar o óvulo.

* OBSERVAÇÃO: a vasectomia é um processo simples, que pode ser realizado com anestesia local, no consultório médico. A operação é considerada irreversível e, portanto, não é indicado para homens que desejam ter filhos posteriormente.

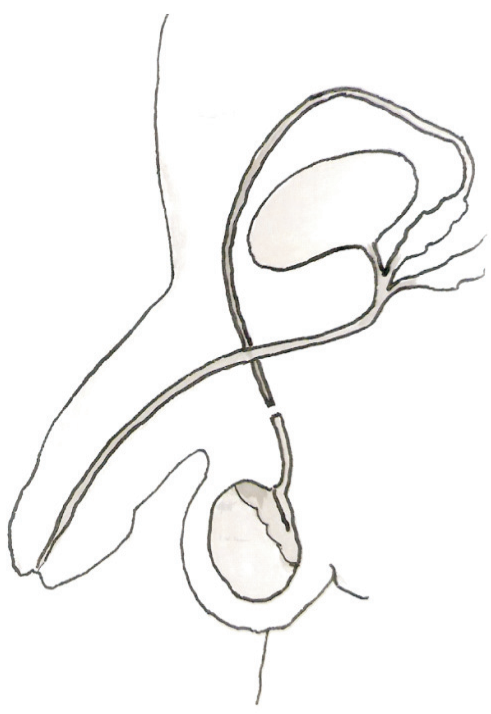

Figura 14 - Vasectomia 


\section{"O adoecer não é mais uma questão do destino. das contigências que podem}

escapar ao controlle. mas que pode ser previnido a partir de escolhas intencionais baseadas em ações racionais bem informadas" Luis David Castiel. 1996 



\section{0 \\ Doenças sexualmente transmissíveis}

Durante o contato sexual, podem ser transmitidas doenças causadas por bactérias, vírus ou outros microorganismos, denominadas Doenças Venéreas (DV) ou Doenças Sexualmente Transmissíveis (DST). Algumas podem ser tratadas e curadas, outras não. Constituem as DST mais comuns:

\section{Sífilis (lues)}

É determinada por bactéria denominada Treponema pallidum, com as seguintes vias de transmissão: relação sexual (genital, oral e anal); mãe/filho, durante a gravidez, contato com as lesões de afetados e transfusão sangüínea. O primeiro sinal da sífilis é a ulceração que desaparece, mesmo sem tratamento, em 7 ou 10 dias, sem deixar cicatriz. Quando não-tratada, pode levar a conseqüências orgânicas graves.

\section{Gonorréia}

Doença bacteriana, causada por Neisseria gonorrhoeae. Os sintomas iniciais (2 a 5 dias após o contágio) são: micção dolorosa e corrimento purulento. Na mulher, muitas vezes é assintomática, podendo, entretanto, levar à esterilidade. 


\section{Candidíase}

Doença feminina, determinada pelo fungo que habita a mucosa vaginal, denominado Candida albicans. Pode ser transmitida via relação sexual, entretanto, algumas mulheres têm predisposição para desenvolverem a infecção. Os principais sinais e sintomas são: corrimento vaginal branco e leitoso; coceira intensa; irritação da vulva e vagina; dor durante o coito e a micção.

\section{Herpes genital}

Doença viral em que não há ainda tratamento para eliminar o vírus. As principais vias de contaminação são a relação sexual e o contato com a lesão. O bebê pode ser contaminado durante o parto. As manifestaçōes da doença constituem a formação de bolhas doloridas na região genital que podem desaparecer. O vírus continua no organismo e, em condiçōes de estresse, podem reaparecer os sintomas.

\section{Uretrite não-específica}

É determinado por diversos tipos de micróbios, via relação sexual. Muitas vezes é confundida com a gonorréia, porque seus primeiros sintomas são também dor à micção e corrimento pelo pênis. Não é particularmente lesiva, respondendo bem ao tratamento medicamentoso. Quando não-tratada corretamente, pode levar a problemas de infertilidade. 


\section{Aids/sida (síndrome da imunodeficiência adquirida)}

Doença causada pelo retrovírus (HIV I e HIV II), que tem o seu material genético constituído de RNA. Para a reprodução, o vírus utiliza o material genético de outra célula, o linfócito T, que comanda a defesa do organismo humano contra agentes infecciosos. Constituem as principais formas de infecção: relaçōes sexuais; transfusão de sangue e hemoderivados; transmissão na gestação de mãe para filho.

Os pacientes que desenvolvem a doença são tratados com as drogas antivirais AZT, DDI e DDC, que inibem a produção da enzima transcriptase reversa, diminuindo a velocidade de replicação do HIV. Um avanço histórico no controle da doença foi dado em 1996 por David Ho, do Centro de Pesquisa da AIDS Aaron Diamond, em Nova York, que propôs o tratamento com um coquetel de drogas que bloqueiam as moléculas de reprodução do vírus. Para isto, é utilizada uma combinação do AZT com outro inibidor da transcriptase reversa, como o 3TC, que inibe a reprodução do vírus no seu estado inicial, associada ao inibidor da protease como o Ritonavir, capaz de interferir no estágio final do ciclo reprodutivo do vírus.

Alteraçōes nos genitais não se incluem entre as manifestações mais comuns da doença. Para que se suspeite de infecção pelo vírus da AIDS, os sintomas não podem ser analisados isoladamente, mas sim em conjunto. Os sintomas mais comuns são:

- suores noturnos

- calafrios

- cansaço profundo

- apatia 
- depressão

- inchaço de gânglios em todo o corpo

- tosse

- diarréia prolongada

- manchas avermelhadas na pele

- emagrecimento exagerado

- febre permanente

Outras DST, entre as quais verrugas sexuais, o linfogranuloma venéreo, os chatos (pequenos ácaros que invadem os pêlos pubianos), o cancro e o condiloma, determinam, em geral, sintomas como ulceração, secreção anormal ou irritação nos genitais etc. Observação dessas manifestações constitui indicação para consulta médica. 


\section{REFERÊNCIAS}

ANDRADE, C.D. Sentimento do mundo. Rio de Janeiro: Record, 1995

ANDRADE, C.D. Claro enigma. Rio de Janeiro: Record, 1992.

AMARILIAN, M.L.T.; PINTO, E.B; GHIRARDI, M.I.G.; LICHTIG, I.; MASICI, E.F.S; PASQUALIN, L. Conceituando deficiência, Rev. Saúde Pública, v. 34, n.1, p. 97-103, 2000.

American Association on Mental Retardation Mental retardation: definition, classification and systems of support. Washington, DC, USA: AAMR, 1992.

American Association on Mental Retardation Mental retardation: definition, classification, and systems of support. Washington, DC, USA: AAMR, 2002.

ASSUMPÇÃO Jr., F.B.; SPROVIERI, M.H.S. Sexualidade e Deficiência Mental. São Paulo: Ed. Moraes, 1987, 83 p.

BAIRD, PA; SADNOVICK, AD. Life tables for Down syndrome. Human Genet. v. 82, p 291-2,1989.

BANDEIRA, M.C.S Bandeira a vida inteira. Rio de Janeiro: Alumbramento, 1986. 90p.

BASTOS, M.; DESLANDES, S.F. Sexualidade e o adolescente com deficiência mental: uma revisão bibliográfica, Ciência \& Saúde Coletiva, v.10, n.2, p. 389-397, 2005.

BELLO, P.; DOLTO C.; SCHIFFMAN, A. Métodos anticoncepcionais. Gravidez. IVC. Guia Prático. Trad. Maria Lúcia Autran Dourado. Rio de Janeiro: J. O. Editora, 1985, 163p.

CAMARGO, A.M.F.; RIBEIRO, C. Sexualidade(s) e Infância(s) - a sexualidade como um tema transversal, São Paulo: Moderna; Campinas: Editora da Universidade de Campinas, 1999.

CARVALHO, E.N.S; MACIEL, D.M.M.A. Nova concepção de deficiência mental segundo a American Association on Mental Retardation AAMR: sistema 2002, Temas em Psicologia da SBP, v.11, n.2, p.147-156, 2003.

CASTIEL, L.D. - Moléculas, moléstias, metáforas: o senso dos humores. São paulo: UnimarCo, 1996.

CAVALCANTI, R.C. (Coord.) Saúde sexual e reprodutiva: Ensinando a ensinar. Brasília: CESEX, FEO e Ministério da Saúde e Educação, 1992, 434p.

COELHO, E.F. Deficiência Sexual: do proibido ao permitido. Porto Alegre: D.C. Luzzatto Ed., 1987.

COUTINHO, E.M. Menstruação, a sangria Inútil: uma análise da contribuição da menstruação para as dores e sofrimentos da mulher. São Paulo: Ed. Gente, 1996, pp. 143-151. COUTINHO, E.M.; ATHAYDE, C. Gossypol, Anais do IV Congresso de Reprodução Humana, 10 (1): 10, 1995.

DECLARAÇÃO DE SALAMANCA. Disponível em: http://muw.dgidc.min-edu.pt/inovbasic/ proj/inclusivas/declaracao-salamanca.doc, 2001. Acesso em 07/02/2007.

DSM-IV. Manual de Diagnóstico e Estatística da Associação Norte Americana de Psiquiatria, Porto Alegre: Artmed, 2002, 880p.

ENGELS, F. A dialética da natureza, Rio de Janeiro: Civilização Brasileira, 1978 
FREINET, E. O itinerário da Celéstin Freinet - a livre expressāo na pedagogia Freinet. Trad. de Priscila de Siqueira, Rio de Janeiro: Livraria Francisco Alves, Ed. S.A., 1979, 164p.

FROTA - PESSOA, O. Genética da deficiência mental, em KRYNSKI, S. Novos Rumos da Deficiência Mental, São Paulo: Ed. Sarvier, 1983, pp.13-26.

GARCIAS, G.L. De "monstros" e outros seres humanos: Pequena História sobre Defeitos Congênitos. Pelotas: EDUCART, 2002.

GAUDERER, E.C. Sexo e sexualidade da criança e do adolescente. Rio de Janeiro: Rosa dos Tempos.

GLAT, R. A integração social dos portadores de deficiências: Uma reflexão, Rio de Janeiro: Sette Letras, 1995, 54p.

GLAT, R.; FREITAS, R.C. Sexualidade e Deficiência Mental: Pesquisando, Refletindo e Debatendo sobre o Tema, Rio de Janeiro: Sette Letras, 1996, 85p.

Guia de Orientação Sexual: Diretrizes e Metodologia. Fórum Nacional de Educação e Sexualidade. Tradução e adaptação: Grupo de Trabalho e Pesquisa em Orientação Sexual, Associação Brasileira Interdisciplinar de AIDS, Centro de Estudos e Comunicação em Sexualidade e Reprodução Humana, São Paulo: Casa do Psicólogo, 1994, 112p.

JACOB, J. O jogo dos possíveis: ensaio sobre a diversidade do mundo vivo. Trad. Luis J. Acher, Lisboa, Gradiva, 1989.

JACQUARD, A. Elogio da diferença, Trad. Álvaro Cabral,São Paulo: Ed. Martins Fontes, 1988.

KRYNSKI, S.; ASSUMPÇÃO Jr., F.B. Problemática sexual do deficiente mental, em KRYNSKI, S.: Novos rumos da deficiência mental, São Paulo. Ed. Sarvier, 1983.

MANTOAN, M.T.E. Inclusão escolar: o que é? por que? como fazer? 2a ed. São Paulo: Modernal, 2006, 64p.

MARCONDES, E. Crescimento normal e deficiente. (Monografias médicas - Série Pediatria), São Paulo, Sarvier Ed.; 1970.

MERIDIEU, F. O desenho infantil. Trad. de Álvaro Lorencini e Sandra M. Nitrini. São Paulo: Editora Cutrix, 1987, 128p.

MIKKELSEN, M; POULSEN, H; NIELSE, KG. Incidence, survival and mortality in Down syndrome in Denmark, Am. J. Méd. Genet. v .7 (suppl): 75-8, 1990.

Ministério de Educação e do Desporto. Parâmetros Curriculares Nacionais para o ensino básico fundamental (10 e 20 ciclos). Brasília, MEC/SEF, 1997.

MOREIRA, L.M.A. A sexualidade do deficiente mental: um mito em questão. Sexus (Estudo Multidisciplinar da Sexualidade Humana), v.2 p. 14-15, 1990.

MOREIRA, L.M.A, GUSMÃO, F.A.F Aspecto s genéticos e sociais da sexualidade em pessoas com Síndrome de Down, Revista Brasileira de Psiquiatria, v. 24, n.2, p. 94-99, 2002.

ORGANIZAÇÃO MUNDIAL DE SAÚDE, 1968. CID - IX. Revisão da classificação internacional de doenças. Porto Alegre: Sagra, 1976.

PIAGET, J. A formação do símbolo na criança. São Paulo: Zahar, 1975.

SECRETARIADO NACIONAL DE REABILITAÇÃO. Classificação Internacional das Deficiências, Incapacidades e Desvantagens (Handicaps): um manual de classificação das conseqüências das doenças (CIDID). Lisboa: SNR/OMS, 1989.

\section{4}


Relatório sobre a saúde no mundo, 2001 - Orģanização Pan Americana de Saúde, Organização Mundial de Saúde - ONU. In PsiqWeb, disponível em unw.psiqwebmed.br/ acad/oms1.html

RODRIGUES, M.L. Teatro de fantoches para crianças. Viçosa: Imprensa Universitária, 1990.

SANTOS, B.S. Entrevista com o professor Boaventura de Souza Santos. Disponível em unw.dhi.uem.br/jurandir_boaven1.htm, 1995.

SCHIAVO, MR (coord) Síndrome de Down: Perfil das percepções sobre as pessoas com Síndrome de Down e do seu atendimento: aspectos qualitativo, Brasília: Federação Brasileira das Associaçōes de Síndrome de Down, 1999.

SECRETARIA DE EDUCAÇ̃̃O FUNDAMENTAL. Ministério de Educação. Parâmetros Curriculares Nacionais: Pluralidade Cultural; Orientação Sexual. 2. ed. Rio de Janeiro: DP\&A, 2000.

SERRÃO, M.; BALEEIRO, M.C. Orientação Educacional: também uma questão de corpo. 1.ed., Salvador: Centro Editorial e Didático da UFBA, 1991, 135p.

SOARES, AHR;NUNES,MC; MONTEIRO, LMC et al. The quality of life of adolescents with spina bífida at the Children's Nacional Medical Center-Washington D.C., Ciência Saúde Coletiva,v 11,n 3,p 817-826, 2006

SPINOLA, P. Anticoncepcional hormonal: recentes avanços sobre injetáveis, In: Congresso Norte-Nordeste de Reprodução Humana, v.10, n 1, p. 7, 1995.

TURK, V. - Mental retardation: Definition, Classification and Systems of Supports, $10^{\text {th }}$ end. Journal of Intellectual Disability Research, v.47, p. 400 - 402, 2003.

TUCKER, P.; MONEY, J. - Os papéis sexuais. Trad.: George Schlesinger. São Paulo: Ed. Brasiliense, 1981, 203p.

WGGOTSKY, L.S. - A formação social da mente. Trad.: José Cipolla Neto, Luis Silveira Menna Barreto e Solange Castro Afeche, 5. ed., São Paulo: Martins Fontes, 1984.

YOZO, R.Y.K. - 100 jogos para grupos, São Paulo: Agora, 1996, 191 p. 



\begin{tabular}{l|l} 
Formato & $\begin{array}{l}\text { Colofão } \\
15 \times 21\end{array}$ \\
Tipologia & $\begin{array}{l}\text { Castle T e Castle T Lig } \\
\text { Fontdinerdotcom Loungy }\end{array}$ \\
Papel & $\begin{array}{l}\text { Alcalino } 75 \mathrm{~g} / \mathrm{m}^{2}(\text { miolo) } \\
\text { Cartão supremo } 250 \mathrm{~g} / \mathrm{m}^{2} \text { ( capa) }\end{array}$ \\
Impressão & $\begin{array}{l}\text { EDUFBA (miolo) } \\
\text { Cian Gráfica (capa) }\end{array}$ \\
Tiragem & 300
\end{tabular}

